\title{
Global analysis of estrogen receptor beta binding to breast cancer cell genome reveals an extensive interplay with estrogen receptor alpha for target gene regulation
}

Oli MV Grober ${ }^{1 \dagger}$, Margherita Mutarelli ${ }^{1 \dagger}$, Giorgio Giurato ${ }^{1}$, Maria Ravo ${ }^{1,2}$, Luigi Cicatiello ${ }^{1}$, Maria Rosaria De Filippo ${ }^{1}$, Lorenzo Ferraro', Giovanni Nassa ${ }^{1,2}$, Maria Francesca Papa ${ }^{1}$, Ornella Paris ${ }^{1}$, Roberta Tarallo ${ }^{1,2}$, Shujun Luo ${ }^{3}$, Gary P Schroth ${ }^{3}$, Vladimir Benes ${ }^{4}$, Alessandro Weisz ${ }^{1,2^{*}}$

\begin{abstract}
Background: Estrogen receptors alpha (ER $\alpha)$ and beta (ERß) are transcription factors (TFs) that mediate estrogen signaling and define the hormone-responsive phenotype of breast cancer (BC). The two receptors can be found co-expressed and play specific, often opposite, roles, with ER $\beta$ being able to modulate the effects of ER $\alpha$ on gene transcription and cell proliferation. ER $\beta$ is frequently lost in $B C$, where its presence generally correlates with a better prognosis of the disease. The identification of the genomic targets of ER $\beta$ in hormone-responsive BC cells is thus a critical step to elucidate the roles of this receptor in estrogen signaling and tumor cell biology.

Results: Expression of full-length ERß in hormone-responsive, ER $\alpha$-positive MCF-7 cells resulted in a marked reduction in cell proliferation in response to estrogen and marked effects on the cell transcriptome. By ChIP-Seq we identified 9702 ER $\beta$ and 6024 ER $\alpha$ binding sites in estrogen-stimulated cells, comprising sites occupied by either ER $\beta$, ER $\alpha$ or both ER subtypes. A search for TF binding matrices revealed that the majority of the binding sites identified comprise one or more Estrogen Response Element and the remaining show binding matrixes for other TFs known to mediate ER interaction with chromatin by tethering, including AP2, E2F and SP1. Of 921 genes differentially regulated by estrogen in $E R \beta+$ vs $E R \beta$ - cells, 424 showed one or more $E R \beta$ site within $10 \mathrm{~kb}$. These putative primary ER $\beta$ target genes control cell proliferation, death, differentiation, motility and adhesion, signal transduction and transcription, key cellular processes that might explain the biological and clinical phenotype of tumors expressing this ER subtype. ER $\beta$ binding in close proximity of several miRNA genes and in the mitochondrial genome, suggests the possible involvement of this receptor in small non-coding RNA biogenesis and mitochondrial genome functions.
\end{abstract}

Conclusions: Results indicate that the vast majority of the genomic targets of ER $\beta$ can bind also ER $\alpha$, suggesting that the overall action of ER $\beta$ on the genome of hormone-responsive BC cells depends mainly on the relative concentration of both ERs in the cell.

\section{Background}

Estrogens are key regulators of cell growth and differentiation in the mammary gland $[1,2]$, where they are involved in the pathogenesis and clinical outcome of breast cancer (BC) [3]. These steroid hormones exert

\footnotetext{
* Correspondence: alessandro.weisz@unina2.it

† Contributed equally

'Department of General Pathology, Second University of Naples, vico L. De Crecchio 7, 80138 Napoli, Italy

Full list of author information is available at the end of the article
}

their effects in normal and transformed mammary epithelial cells by binding to specific receptors, ER $\alpha$ and ER $\beta$, that mediate estrogen signaling by functioning as ligand-dependent transcription factors. Ligand-activated ERs drive gene cascades comprising primary genes, whose transcription is directly controlled by the hormone through physical interaction of ERs with regulatory sites in the genome (genomic pathway) and/or with signal transduction effectors (non genomic pathway), as well as
C Biomed Central

(c) 2011 Grober et al; licensee BioMed Central Ltd. This is an Open Access article distributed under the terms of the Creative Commons Attribution License (http://creativecommons.org/licenses/by/2.0), which permits unrestricted use, distribution, and reproduction in any medium, provided the original work is properly cited. 
downstream genes whose activity depends upon the functions encoded by the primary responders $[1,4]$.

ERs are able to bind DNA at specific sites in the genome and thereby control gene activity by recruiting transcriptional mediators and co-regulators, as well as a host of other nuclear proteins with different roles in ERmediated control of gene activity $[5,6]$. The two ERs show $55 \%$ identity in their estrogen-binding domains (LBDs) and approximately $97 \%$ similarity in the DNAbinding domains (DBDs) [7]. Reflecting the high degree of similarity in their DBDs, both receptors interact with the same conserved estrogen response element (ERE) (5'GGTCAnnnTGACC-3') as either homodimers or alpha/ beta heterodimers $[8,9]$. ER $\beta$, however, holds low transacting capability on ERE-containing estrogen target genes and alpha/beta heterodimers are less efficient than ER $\alpha$ homodimers in promoting target genes activity [10]. The different behaviour of ER $\alpha / E R \beta$ heterodimers respect to $E R \alpha$ homodimers on transcriptional regulation of ERE-containing genes might be explained by different co-factor recruitment, as ER $\beta$ could prevent efficient co-activator binding to the ER $\alpha$ moiety of the heterodimer, conversely inducing recruitment of co-repressors and/or driving assembly of co-regulatory complexes other than those involving ER $\alpha$ only. [8,11,12].

Although the two receptors are quite similar in sequence and structure, in BC ER $\beta$ has considerably different biological effects than ER $\alpha[1,13,14]$. Furthermore, the two ERs show a remarkably different expression pattern in BCs, with higher ER $\alpha$ and lower ER $\beta$ levels observed in malignant cells compared to normal mammary epithelial or benign tumor cells $[15,16]$. Furthermore, while ER $\alpha$ induces a mitogenic response to estrogen, when expressed alone the $\beta$ subtype is not only unable to induce the same mitogenic response, but it reduces basal, hormone-independent cell proliferation [17-18 and R. Tarallo et al., unpublished]. Finally, ER $\beta$ was shown to change dramatically ER $\alpha$-positive BC cell behaviour in vivo, as its expression in the cell prevents tumorigenicity in mouse xenograft models by reducing tumor growth and angiogenesis $[19,20]$.

Gene expression studies performed in $\mathrm{BC}$ cell lines expressing endogenous $E R \alpha$ and recombinant ER $\beta$ [21-23] revealed multiple signaling pathways involving the $\alpha$ and/or $\beta$ receptor subtypes [1]. The two ERs appear thus to share many target genes, although each of them may affect specific downstream targets. For this reason, inhibition of hormone-responsive BC cell growth by $\operatorname{ER} \beta$ might be due to direct interference with $E R \alpha$ activity on growth-promoting pathways as well as to the activity of ER $\beta$-specific target genes [24].

Recently, next-generation sequencing technologies combining chromatin immunoprecipitation (ChIP) either with genomic DNA hybridization to microarrays
(ChIP-on-chip) or massively parallel sequencing (ChIPSeq, ChIP-PET), opened new venues for our understanding of physical and functional associations between transcription factors and chromatin in vivo. These analytical strategies led to genome-wide mapping of ER $\alpha$ binding regions in intact chromatin of cultured cell lines [25-28], revealing important new information relative to $\mathrm{ER} \alpha$ interaction with the genome. Carroll et al. [25], for example, using ChIP-on-chip demonstrated that the Forkhead factor FoxA1 plays an important role as pioneering factor for ER $\alpha$ binding to chromatin in BC cells, while Cicatiello et al. [26] identified novel gene regulation cascades mediating estrogen actions in hormoneresponsive $\mathrm{BC}$ cells. In contrast, although several studies focused on ER $\beta$ interaction with the genome [29-32], a thorough characterization of this important aspect of ER $\beta$ biology in BC cells, essential to clarify the mechanisms mediating its control of estrogen-dependent gene pathways and the hormone-responsive phenotype, is still missing. For this reason, we performed a comprehensive analysis of ER $\beta$ and ER $\alpha$ target sites in the genome of MCF-7 cells engineered to express both receptors to comparable levels, by integrating global mapping of in vivo ER binding to the genome by ChIP-Seq with comparative gene expression profiling in $E R \beta+/ E R \alpha+v s$ ER $\beta$-/ER $\alpha+$ cells during early stimulation with 17-betaestradiol (E2), followed by in silico analyses of the ER $\beta$ binding regions and responsive genes identified.

\section{Results and Discussion}

\section{Establishment and characterization of ER $\beta$-expressing MCF-7 cells}

Stabilized human $\mathrm{BC}$ cell lines expressing endogenous $\mathrm{ER} \alpha$ and ER $\beta$ at comparable levels are not available. For this reason, we first generated and characterized cell lines derived from ER $\alpha$-positive MCF-7 cells expressing full-length human ER $\beta$ (ER $\beta 1$ ) at levels similar to those of endogenous ER $\alpha$. This strategy was adopted to prevent artefacts due to ER $\beta$ over-expression in the cell and to mimic what observed in primary breast tumors, where very high expression of this receptor has never been observed. As suitable antibodies for efficient immunoprecipitation of chromatin-bound ER $\beta$ are not available, the expressed proteins were tagged on either their C- $(\mathrm{Ct}$-ER $\beta)$ or $\mathrm{N}$-terminus $(\mathrm{Nt}-\mathrm{ER} \beta)$ with the TAP epitope. This approach allows to track tagged ERs in different cell compartments and to efficiently immunoprecipitate and purify them in vitro by Tandem Affinity Purification, to identify their molecular partners [5,33], and ex vivo in chromatin immunoprecipitation assays (see below). Preliminary tests were performed to verify whether the presence of the TAP moiety could influence intracellular redistribution of ER $\beta$ in response to $17 \beta$-estradiol (E2) and its ability either to trans-activate an 
estrogen-responsive reporter gene or to interfere with $\mathrm{ER} \alpha$ activity on reporter gene transcription and $\mathrm{BC}$ cell proliferation. To this end, ER expression and nuclear translocation in response to E2 was determined in $w t$ MCF-7, Ct-ER $\beta$ and Nt-ER $\beta$ cells by subcellular fractionation followed by SDS-PAGE and immunoblotting (Figure 1A). In absence of hormone a larger fraction of both ERs was found in the cytosol in all cases. Following estrogen stimulation, both receptors migrated to the nucleus, a crucial event to trigger target gene transcription via the genomic pathway of the estrogen signaling cascade. An antibody against $\alpha$-tubulin was used as control, and the absence of this protein in the nuclear fractions indicates that they were indeed free from cytosolic contaminants. The ER $\beta$-expressing clones selected for this study showed a ER $\beta / E R \alpha$ ratio $<2$, as verified by immunoblotting analysis of the proteins in whole cell extracts and quantitative rtPCR of the corresponding RNAs [5, and data not shown]. To control that the presence of the TAP tag did not interfere with ER $\beta$ activity, ER-negative SKBR-3 BC cells were transiently transfected with expression vectors encoding $w t \mathrm{ER} \beta, \mathrm{Ct}$ $\mathrm{ER} \beta, \mathrm{Nt}-\mathrm{ER} \beta, \mathrm{ER} \alpha$ (HEG0) or 'empty' vector (pSG5), as controls, and ERE- $t k$-luc [34], a reporter gene where luciferase expression is driven by an estrogen-responsive minimal promoter. Exposure of transiently transfected cells to E2 induced reporter gene activation in the presence of ER $\alpha, E R \beta, C t-E R \beta$ or Nt-ER $\beta$, with the activity of both tagged ER $\beta$ proteins slightly (15-20\%) lower than that of $w t$ ER $\beta$ (Figure $1 \mathrm{~B}$, left). We then tested whether the two recombinant forms of ER $\beta$ were able to interfere with target gene activation by the endogenous ER $\alpha$ resident in MCF-7 cells. To this end, $w t, \mathrm{Ct}-\mathrm{ER} \beta+$ and $\mathrm{Nt}-\mathrm{ER} \beta+$ cells were transfected with ERE- $t k$-luc and the response of the reporter gene to E2 was determined. As shown in Figure 1B (right), ER $\beta$ expressing cells showed in all cases a marked (50-60\%) reduction in reporter gene response to the hormone, when compared to $w t$ MCF-7 cells, indicating that both tagged ER $\beta$ s are able to interfere with the activity of endogenous ER $\alpha$. Results show that cell lines stably expressing Ct-ER $\beta$ and Nt-ER $\beta$ display a marked reduction in proliferative response to the hormone, when compared to $w t$ MCF-7 cells (Figure 1C), in agreement with the known effects of ER $\beta$ in ER $\alpha$-positive cells [23,35-37]. Furthermore, comparative RNA expression profiling in exponentially growing $\mathrm{Ct}-\mathrm{ER} \beta$ and Nt-ER $\beta$ vs $w t$ MCF-7 cells revealed extensive overlapping effects of the two tagged ER $\beta$ proteins on the activity of estrogen target genes [O. Paris et al., manuscript in preparation and data not shown]. Taken together, these

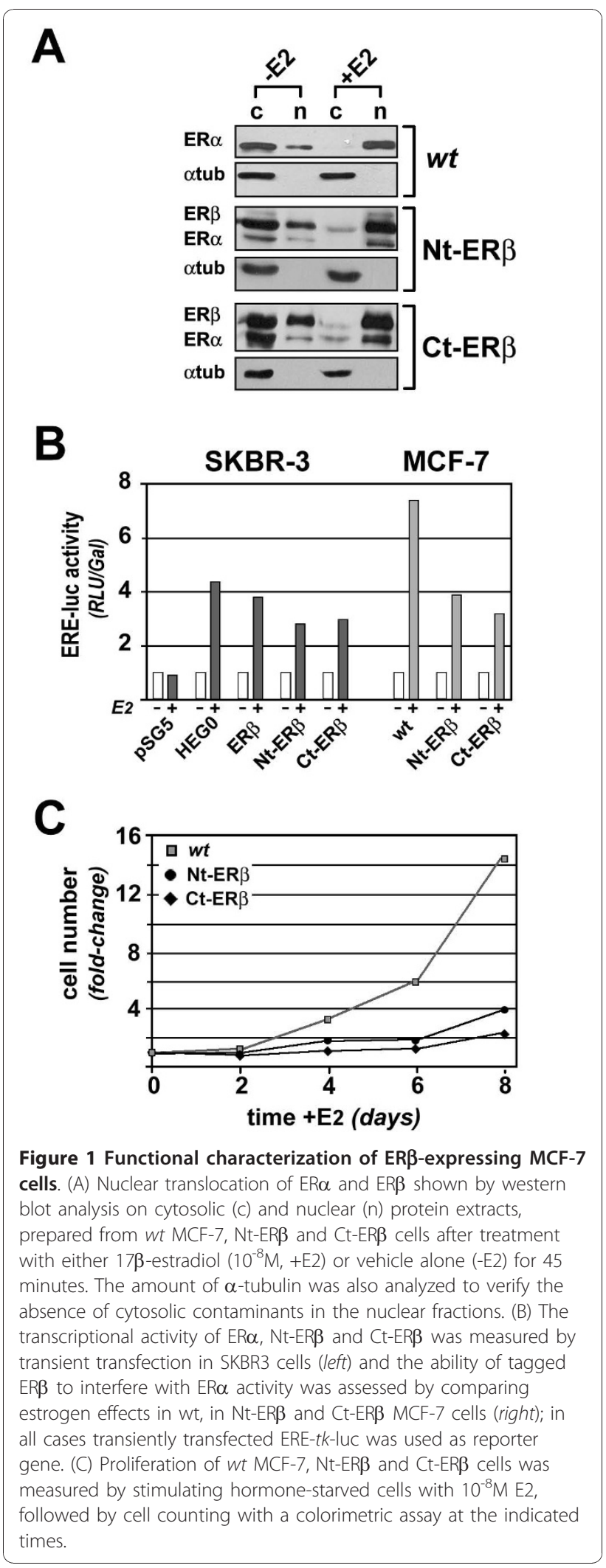


observations confirmed that both tag-ER $\beta$ expressing cell lines generated for this study show a well defined phenotype, with respect to the known activities of this ER subtype in BC cells, and are thus suitable to investigate the genomic bases of ER $\beta$ actions in this cell type. As we could not exclude that the presence of the TAP tag at either the $\mathrm{N}$ - or $\mathrm{C}$ - term of ER $\beta$ may specifically influence its activity on cellular targets or pathways different from those investigated above, all experiments reported in this study were performed in both Ct-ER $\beta$ and Nt-ER $\beta$ cells and the data were combined for analysis, with the aim to focus on the most significant and reproducible actions of ER $\beta$ independently from position of the tag in the receptor moiety.

\section{Effects of ER $\beta$ on the estrogen-responsive MCF-7 cell transcriptome}

Expression of ER $\beta$ is known to cause significant changes in the genomic response to estrogen in target cells. To identify the genes whose estrogen regulation in hormone-responsive $\mathrm{BC}$ cells is perturbed by $\mathrm{ER} \beta$, we performed gene expression profiling with microarrays in estrogen-starved, quiescent $w t$ and TAP-ER $\beta+(\mathrm{Ct}-\mathrm{ER} \beta$ and Nt-ER $\beta$ ) MCF-7 cells following stimulation with $10^{-8} \mathrm{M}$ E2. Total RNA was extracted from the three cell lines either before or after 2, 4 or $8 \mathrm{hrs}$ stimulation, fluorescently labelled and analyzed on whole-genome microarrays. Samples extracted from the two ER $\beta$-expressing cell lines were pooled before analysis, to reduce the impact of clone-specific differences and to focus on the most significant effects of ER $\beta$, independent from tag position in the protein. Results obtained in these samples were then compared with those obtained under the same conditions in $w t$ MCF-7 cells. This analysis yielded 921 transcripts differentially regulated by the hormone in $\mathrm{ER} \beta+v s \mathrm{ER} \beta$ - cells (Figure 2), including 234 mRNA whose regulation was detected only in $w t$ MCF-7 cells, 516 regulated only in ER $\beta$ + cells (see Venn diagram in Figure 2), 154 showing a similar pattern of response in both cell types (up- or down-regulated in all cases, although at different levels) and 17 showing opposite responses to the hormone in ER $\beta+v s \mathrm{ER} \beta$ - cells (14 transcripts repressed in $w t$ cells but activated in ER $\beta+$ cells and 3 showing an opposite behaviour). The full list of these differentially regulated transcripts is reported, with relevant information, in Additional Table S1. Taken together, these results indicate that the presence of ER $\beta$ greatly influences the response of the MCF-7 cell genome to estrogen, by interfering with $\mathrm{ER} \alpha$-mediated hormonal regulation of 405 genes (Figure 2, left and central panels) and promoting de novo regulation of 516 genes (Figure 2, right panel). It should be noted that these analyses were performed with data obtained after 8 hrs of hormonal stimulation, a timing that allowed us to focus on early

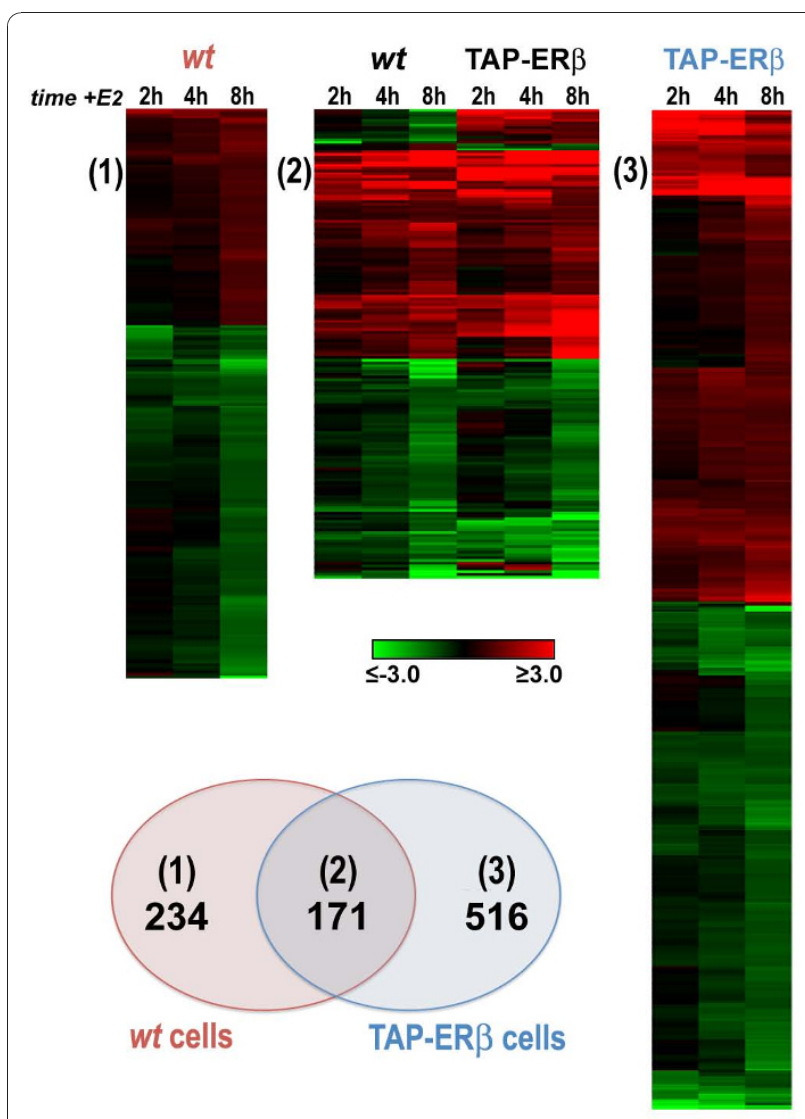

Figure $\mathbf{2}$ Gene expression differences in absence or presence of ER $\boldsymbol{\beta}$. Top: Heatmap summarizing the effects of ER $\beta$ expression of the estrogen responsive transcriptome of MCF-7 cells, showing changes in expression ( $\log _{2}$ of the fold-change) of 921 transcripts after cell exposure to $10^{-8} \mathrm{M}$ E2 for the indicated times. Transcripts are grouped as follows: regulated only in wt MCF-7 cells (1), in both cell lines (2) and only in TAP-ERß cells (3). Bottom: Venn diagram showing the numbers of differentially regulated by E2 in wt MCF-7 only (1), both cell lines (2) or ERß expressing cells only (3).

response genes, positioned upstream in the composite transcriptional cascade set in motion by the hormone in this cell type and more likely to include primary genomic targets of ERs [26]. It is thus possible that this analysis missed ER $\beta$-responsive genes showing significant changes in expression only at later times after hormonal stimulation. However, analysis of the global effects of ER $\beta$ on gene expression in these same cells, performed as described above in cultures exponentially growing under continuous hormonal stimulus, suggests that the number of regulated transcripts identified here is rather close to the total number of genes targeted by this ER subtype in MCF-7 cells [O. Paris et al., manuscript in preparation].

\section{Global mapping of ER $\alpha$ and ER $\beta$ binding to MCF-7 cell genome}

The widespread effects of ER $\beta$ on MCF-7 cell transcriptome are likely to result from multiple effects of this 
receptor in the cells, including direct regulation of primary response genes via genomic or non genomic mechanisms, and indirect gene regulation events mediated by the products of primary genes. The primary ER $\beta$ target genes are most likely to comprise also master regulators of complex cellular responses to the receptor, mediating its effects on the biological and clinical phenotype of $\mathrm{BC}$ cells. To identify such primary genomic targets and investigate the mechanisms that allow their regulation by ER $\beta$, a global analysis of in vivo binding of this receptor to the genome was carried out in TAPER $\beta$ cells by chromatin immunoprecipitation coupled to massively parallel sequencing (ChIP-Seq) [38], that allows detailed mapping of in vivo TF binding to the genome. In parallel, we studied ER $\alpha$ binding to the genome under the same conditions, to allow comparative analyses between the two ER subtypes. Replicate chromatin samples were prepared from both Ct-ER $\beta$ and Nt-ER $\beta$ cells before and after stimulation for 45 minutes with $10^{-8} \mathrm{M}$ E2 and DNA-bound proteins were immunoprecipitated either with antibodies against the $\mathrm{N}$ - and C-terminus of ER $\alpha$, or with IgGs binding with high affinity the TAP moiety of tagged ER $\beta$ (see Methods). Preliminary testing on several known ER $\beta$ binding sites, including the promoter-near region of $\mathrm{pS} 2 / \mathrm{TFF} 1$ gene [26], confirmed that the method selected to immunoprecipitate chromatin-bound Ct-ER $\beta$ and Nt-ER $\beta$ was efficient and specific (data not shown). The resulting DNAs were used to generate ChIP-Seq libraries for ER $\alpha$ and $E R \beta$, respectively, that were then sequenced with the Illumina Genome Analyzer. The sequence tags obtained were then aligned to the human genome sequence and peaks enriched in the libraries generated after E2-treatment were identified using MACS (Model-based Analysis of ChIP-Seq) [39]. This led to the identification of 9702 binding sites for ER $\beta$ and 6024 sites for ER $\alpha$, of which 4506 were shared by both receptors (Figure 3A), with an average False Discovery Rate (FDR) of 3\%. The full list of these binding sites is available, with relevant information, in Additional Files 1 and 2. Interestingly, about half (4862) ER $\beta$ binding sites identified map within transcription units, mainly (3942 sites) in intronic regions. This distribution is maintained also in 424 ER $\beta$ regulated transcription units (see below), where 966 ER $\beta$ binding sites located in the gene or within $10 \mathrm{kbps}$ from it are distributed as follows: 154 in promoter regions, 51 in exons, 471 within one or more introns and the remaining either upstream of promoters (156) or downstream of the gene (134). In both cases the ER $\beta$ binding sites within genes did not show any preference with respect to exon or intron position nor for know intragenic regulatory elements (splice sites, polyadenylation sites, etc). It should be mentioned that the number of ER $\beta$ binding sites identified is significantly higher that

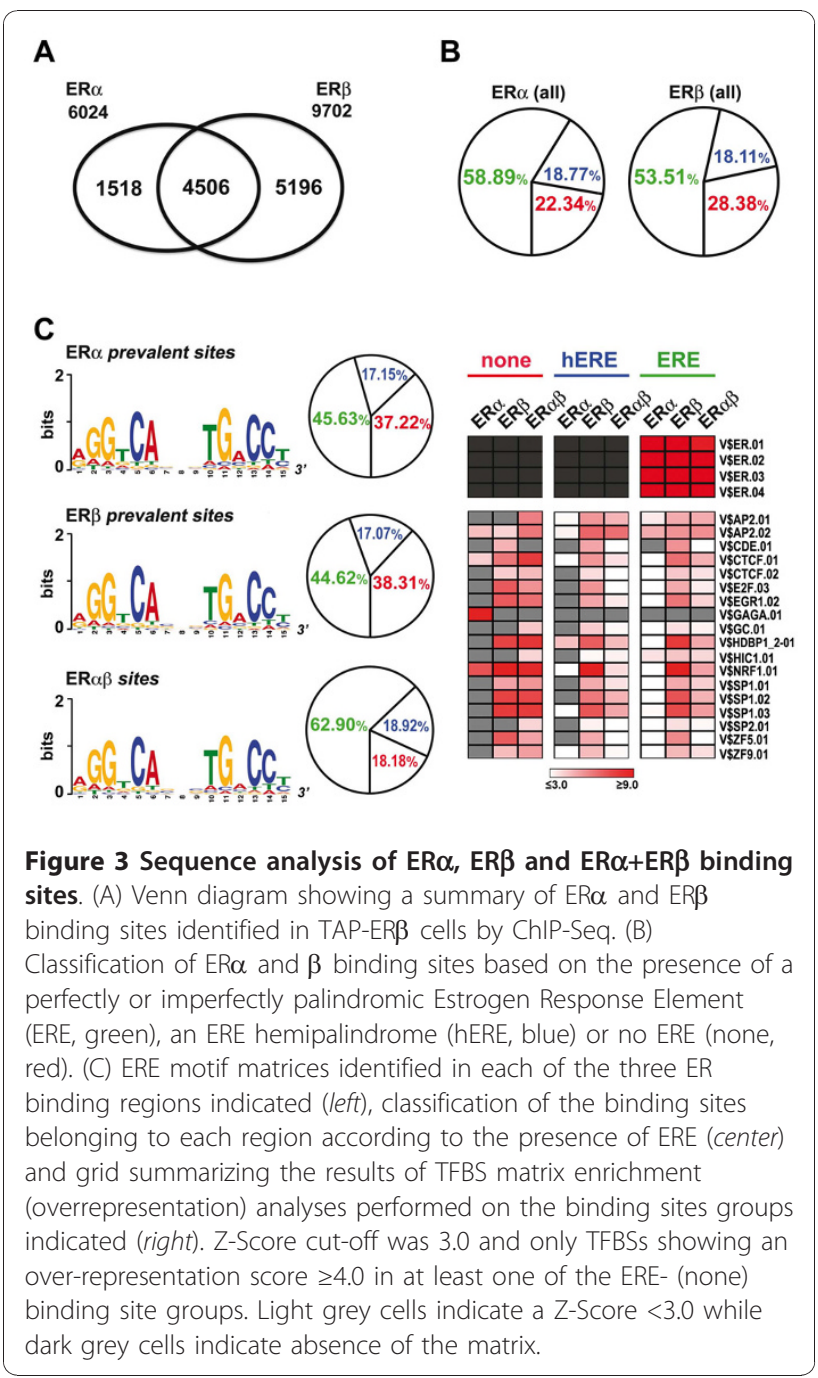

those mapped in MCF-7 cells by ChIP-on-chips [30,31], possibly for technical differences due to ER $\beta$ expression levels in the different MCF-7 cell-derived clones used, in immunoprecipitation efficiency and/or in DNA analysis. Since only Zhao et al. [31] performed an unbiased search for ER $\beta$ binding with whole-genome chips, we could confront our results only with those reported in that study. This showed that $86 \%$ of high confidence ER $\beta$ sites described in that study appear also in our dataset. The binding sites identified here were then subjected to sequence analysis, searching first for the presence of EREs (Estrogen Receptor Elements), the characteristic ER binding signature (Figure 3B). This analysis revealed that in all three cases (i.e. ER $\beta, E R \alpha$ and $E R(\beta+E R \alpha)$ a high percentage of sites displayed one or more imperfectly palindromic ERE (ERE+), with a slightly higher positivity in ER $\alpha$ sites (58.89 vs 53.51\%). As ERs have been shown to bind both in vitro and in vivo to PuGGTCA hemi-palindromes (hEREs), we 
searched the sequence of the remaining (ERE-) sites for perfect matches to this sequence. Results showed that almost half of them indeed contained one or more hEREs. The percentages of sites not carrying a known ER-binding element (ERE- and hERE-) were similar for both receptors (ER $\alpha: 22.34 \%, E R \beta: 28.38 \%$ ). We observed that ER $\alpha$ and ER $\beta$ binding sites were often found in close proximity to each other, a confounding factor when attempting to discern and analyze separately ER subtypespecific sites and target genes. This could be due to the limits of the ChIP-Seq technology or of the algorithm used for peak selection. To overcome this problem, and allow the identification of potential ER subtype-specific sites, we used a cartographic approach to group nearby binding sites that might be the result, at least in part, of shortfalls of the mapping methods applied. Each binding peak was thus elongated in both directions by $1000 \mathrm{bp}$ and the overlapping ones obtained were merged into $8536 \mathrm{ER} \beta$ and $5371 \mathrm{ER} \alpha$ 'extended' binding regions. These regions were intersected to define ER $\alpha$ only, ER $\beta$ only or ER $\alpha+E R \beta$ binding regions. In this way we could identify 1271 ER $\alpha$-only and 4541 ER $\beta$-only binding sites, comprised in these regions, none of which showed nearby binding of the other receptor. These were named: ER subtype 'prevalent' sites. The binding peak sequences included in each of the three regions obtained (ER $\alpha$ only, ER $\beta$ only or ER $\alpha+E R \beta$ ) were then re-analyzed for the presence of ERE or hERE elements. In this way we could observe that sites within the ER $\alpha+E R \beta$ regions showed now a much higher percentage of ERE+ sequences (62.90\%), respect to those present in the ER $\alpha$-only or ER $\beta$-only regions $(45.63 \%$ and $44.62 \%$, respectively, Figure 3 C). Since all three types of sites showed almost identical proportions of hERE+, this result suggests that perfectly or imperfectly palindromic EREs are preferential binding sequences for ER $\alpha$-ER $\beta$ heterodimers, while ER $\alpha$ and ER $\beta$ homodimers appear to be more flexible in DNA recognition. ERE+ sequences were then analyzed in more detail with MEME [40], to investigate if the three classes of sites identified showed any difference in the relative base composition of their respective ERE signatures. For each list of sequences, the most significant positionspecific probability matrix generated by MEME was compared to the matrices present in the JASPAR transcription factor binding profile database [41], using the STAMP tool-kit for DNA motif comparison [42]. As shown in Figure 3C (left panels), this analysis revealed that the ERE matrices derived from the three types of binding regions identified (ER $\alpha$ selective, ER $\beta$ selective and $E R \alpha+E R \beta$ ) are identical and, as a consequence, that ER $\beta$ does not appear to display ERE variant selectivity.

We then examined the ERE- sequences to search for enriched binding motifs for other transcription factors that might play a role in ER binding to chromatin in the absence of canonical EREs. ERs are known to be able to bind chromatin indirectly, by physically interacting with DNA-bound TFs (tethering), including SP1 $[43,44]$ or the AP1complex $[31,45,46]$, for gene trans-regulation. TFBS enrichment respect to the whole genome was calculated thus in ERE- sites with using the RegionMiner tool [47] and only statistically significant (Z-score $\geq 3.0$ ) and highly enriched (over-representation $\geq 4$-fold) matrices were further considered. The results are summarized in the right panel of Figure 3C, showing for comparison the over-representation values scored in hERE + and ERE + sites by the same matrices selected in the ERE- sites. These numerical values, together with relevant information, are reported in Additional Table S2 [Additional file 3]. The enriched matrices found in the ERE- set of ER $\beta$ prevalent sites include V\$SP1.01, V \$SP1.02, V\$SP1.03, V\$SP2.01 and V\$GC.01, all belonging to the GC-Box family targeted by SP1 and GCFC1 (GC-rich sequence DNA-binding) factors, V\$CTCF.01 and V\$CTCF.02, binding site matrices for the CCCTCbinding factor CTCF, that is a known transcriptional repressor of c-myc [48], V\$NRF1.01, binding NRF1 (nuclear respiratory factor 1), a transcription factor that regulates the expression of nuclear-encoded mitochondrial genes [49], V\$ZF5.01, for the POZ domain zinc finger protein ZF5, and V\$ZNF9.01, recognized by the zinc finger proteins ZNF148, 202, 219 and 281. The majority of these TFs bind GC- and C-rich sequences that are structurally related to each other, suggesting the possibility that a significant portion of the sequence elements listed above might indeed be recognized by one or a limited number of TFs. On the other hand, the V\$GAGA.01 matrix was specifically enriched only in the ER $\alpha$ prevalent ERE- binding sites. This sequence binds a transcription factor known to influence chromatin structure in Drosophila [50] and to bind throughout the genome [51], but nothing is known about physical or functional interactions of this factor with ERs or other nuclear receptors. The results of this analysis point to TFs that could act as partners of ER $\beta$ for binding to chromatin in the absence of canonical EREs. Interestingly, the majority of these same matrices were found enriched also in the ER $\beta$ binding sites comprising hEREs or EREs (Figure 3C), suggesting that one or more such DNA matrices might cooperate with ER $\beta$ for either DNA binding or gene trans-regulation. We performed a direct search for conserved motifs in the ERE- binding sites of ER $\beta$ with MEME [40], and the most significant position-specific probability matrices were compared to those present in the JASPAR TF binding profile database [41]. The results failed to provide any conclusive information, as each of several sequence motifs obtained with this analysis was found only in a small fraction of the binding sites analyzed. 


\section{Identification of primary ER $\beta$ target genes}

To identify the genes directly controlled by ER $\beta$ binding to the genome, and analyze the interplay between the two ERs in gene regulation, we combined the ChIP-Seq data with those relative to estrogen responsive genes differentially regulated by E2 in ER $\beta+v s$ ER $\beta$ - MCF-7 cells under the same experimental conditions (Figure 2). Three sets of ER binding regions (defined as described in Methods) were used for this analysis: ER $\beta$ (8872, Set 1) and $E R \alpha$ (5558, Set 2) binding regions identified in TAP-ER $\beta$ cells, and all ER $\alpha$ binding regions identified so far in $w t$ MCF-7 (17888, Set 3). The regions from Set 1 (ER $\beta$ in ER $\beta+$ cells) were intersected with those from Set 2 (ER $\alpha$ in ER $\beta$ + cells), to define which of them was binding both receptor subtypes ('heterodimer ER $\alpha+E R \beta$ ': 4186), only ER $\beta$ ('homodimer ER $\beta$ ': 4686) or only ER $\alpha$ ('homodimer ER $\alpha$ ': 1372) in TAP-ER $\beta$ cells. The 'homodimer ER $\beta$ ' and the 'heterodimer ER $\alpha+E R \beta$ ' groups were further filtered against Set 3 binding regions (ER $\alpha$ sites detected in ER $\beta$ - cells), to identify the genomic sites recognized by ER $\beta$, with or without $E R \alpha$, but never by $\mathrm{ER} \alpha$ alone. This allowed us to classify the sites comprised in these regions as follows: Class 1, including 2126 sites occupied by ER $\alpha$ in $w t$ MCF-7 cells and by ER $\beta$ in TAP-ER $\beta$ cells (ER $\beta$ vs ER $\alpha$ competition); Class 2, showing 4340 sites where ER $\alpha$ can bind in $w t$ MCF-7 cells and both receptors are detected in TAP-ER $\beta$ cells $(E R \beta+E R \alpha)$; Class 3, with 2707 sites binding only ER $\beta$ and never, under any condition, ER $\alpha$ (ER $\beta$ specific); Class 4, comprising 529 sites where both receptors are found in TAP-ER $\beta$ cells but none in $w t$ MCF-7 cells $(E R \beta+E R \alpha$ specific); Class 5, including 617 sites where $\mathrm{ER} \alpha$ binds only in TAP-ER $\beta$ but never in $w t$ cells (ER $\alpha$ displacement); Class 6, composed of 773 sites that bind only ER $\alpha$ both in $w t$ and TAP-ER $\beta$ cells (ER $\alpha$ specific). When combined with the results of the sequence analyses described above, this classification reveals that ER $\beta$-specific cis-acting regulatory elements are unlikely to exist in the genome, as all evidence point to the fact that the two ER subtypes can recognize identical sequence features.

To identify among the genes differentially regulated by estrogen in ER $\beta+v s E R \beta$ - cells those representing direct targets for transcriptional regulation by DNA-bound ER $\beta$ in our cell model, we extracted from the list in Additional Table S1 [Additional file 3] the genes bearing one or more ER $\beta$ binding sites inside or within $10 \mathrm{~kb}$ of the TU, and termed them 'primary', to indicate that they are most likely to respond directly to the signal conveyed by the E2-activated receptor [26]. Of these 424 genes - listed in Additional Table S3 [Additional file 3 ], whose kinetics of response to E2 in $w t$ and TAP-ER $\beta$ cells is shown in Figure 4, 52 show one ER $\beta$ site of Class 1 (ER $\beta$ vs ER $\alpha$ competition), 90 a site of Class 2
$(E R \beta+E R \alpha), 71$ a site of Class 3 (ER $\beta$ specific) and only 9 a Class 4 site (ER $\beta+E R \alpha$ specific), while 202 showed multiple ER $\beta$ sites belonging to different classes and were thus classified accordingly (grey in Figure 4). In the right panels of Figure 4 are reported examples for each of the primary gene classes described above, showing the location of the receptor binding sites respect to the promoter and structural gene. It is worth mentioning that when the gene expression data from $w t$ MCF-7 cells stimulated with E2 for 8hrs (Figure 2) were combined with information concerning ER $\alpha$ binding regions identified in $w t$ MCF-7 cells under comparable conditions (Set 3 described above), 228 putative primary ER $\alpha$ target genes were identified -listed in Additional Table S4 [Additional file 3], 71\% of which (163 genes) showed ER $\beta$ binding in hormone-stimulated ER $\beta+$ cells. This result supports the view that the two ER subtypes tend to interact with the same targets in $\mathrm{BC}$ cells genome.

A functional analysis of the primary ER $\beta$ target genes identified here with Ontologizer [52] showed that most primary ER $\beta$ responsive genes are involved in key cellular processes, including control of cell proliferation, survival and differentiation status as well as cell motility, migration and adhesion, and can all greatly influence $\mathrm{BC}$ cell phenotype and response to estrogen - listed in Additional Table S5 [Additional file 4]. When GO analysis was performed on the ER $\alpha$ target gene set from $w t$ MCF-7 cells (228 genes), results showed that the genes controlled directly by this ER subtype appear to be involved in the same cellular processes described above for ER $\beta$-compare results reported in Additional Tables S5 and S6 [Additional files 4 and 5], providing a further indication of the significant overlapping between gene pathways targeted by ER $\beta$ and ER $\alpha$ in BC cells. Focusing on the genes differentially regulated by E2 in ER $\beta$ - vs ER $\beta+$ cells known for their involvement in cell proliferation, we observed that many of them encode for transcription factors and other key proteins controlling large gene networks of cell division cycle and cell survival and, in general, cell proliferation and differentiation pathways. These include, in particular, CDK-6 (cyclin-dependent kinase 6), CEBPA (CCAAT/enhancer binding protein, alpha), DAB2 (Disabled homolog 2, mitogen-responsive phosphoprotein), HES-1 (Hairy and enhancer of split homologue 1), IGFBP-4 (Insulin-like growth factor binding protein 4), IRS-1 and -2 (Insulin receptor substrates 1 and 2), JAK-2 (Janus kinase 2), JunB, MITF (Microphthalmia-associated transcription factor), MYC, SLIT-2 (Slit homolog 2, Drosophila), SMARCA-2 (SWI/SNF related, matrix associated, actin dependent regulator of chromatin, subfamily a, member 2), SOX-9 (Sex determining region Y-box 9), TGFB-2 (Transforming growth factor beta 2), TGFBI/LCD-1 (transforming growth factor, beta-induced, $68 \mathrm{kDa}$ ), TGM-2 (Transglutaminase 2), 


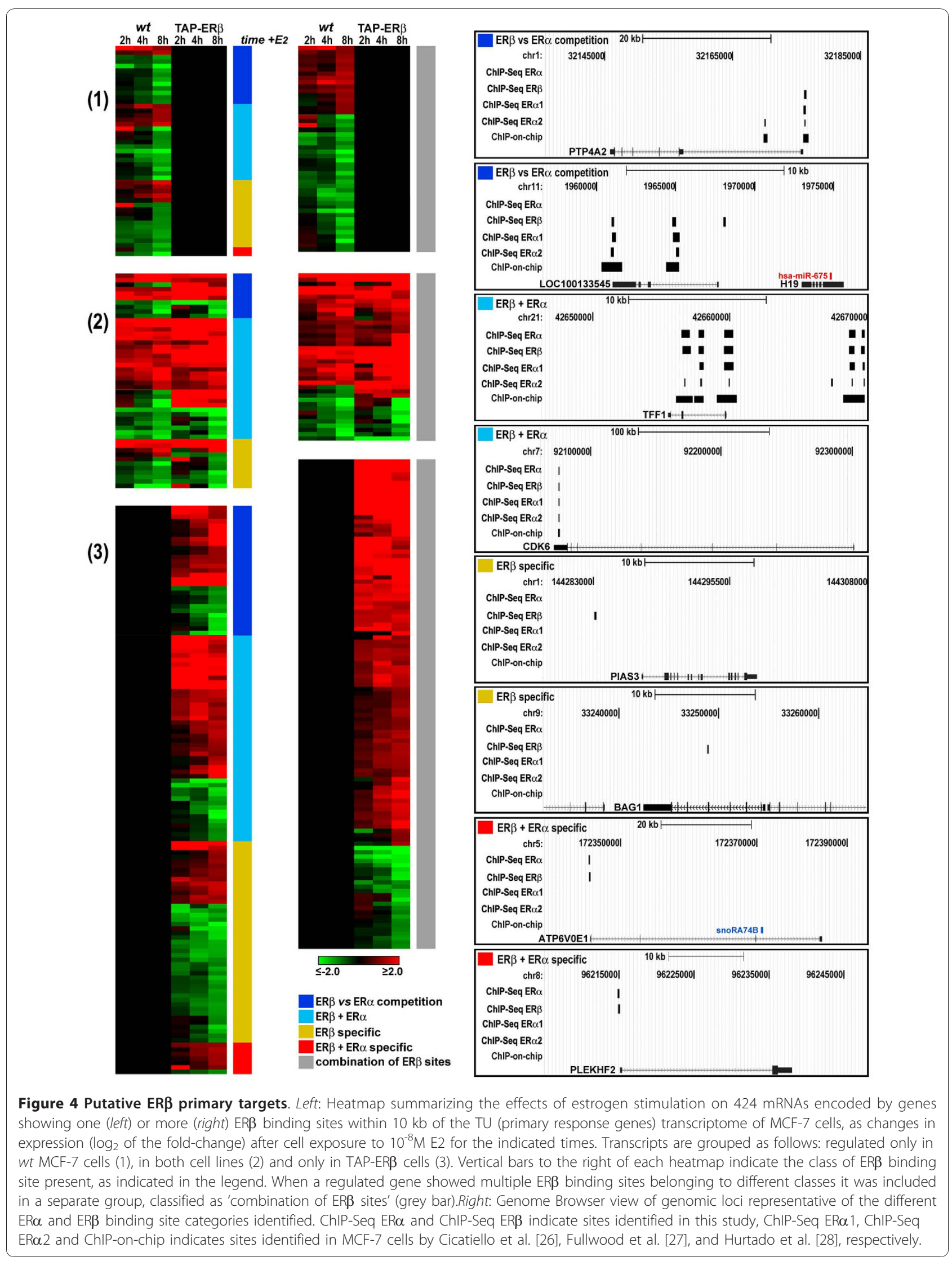


TNS-3 (Tensin 3) and WISP-2 (WNT1 inducible signaling pathway protein 2). Interestingly, the role of all these genes in tumor cell proliferation and differentiation is known and an involvement in hormone-mediated $\mathrm{BC}$ cell responses to $E R \alpha$ has been reported for most of them, suggesting that discovery of an ER $\beta$ direct effect on transcription of these genes provides a new molecular framework to elucidate the anti-proliferative and differentiative effects of this receptor subtype in hormone-responsive cells.

Among the RNAs encoded in the genome, microRNAs (miRNAs) have emerged as master regulators of gene expression for their ability to influence mRNA concentration and activity by post-transcriptional mechanisms. Recent results highlighted the role of miRNA in BC cells response to estrogen [26,53-58] and, in addition, several lines of evidence indicate extensive miRNA deregulation in $\mathrm{BC}$, including differential expression of miRNAs in normal $v s$ transformed mammary epithelial cells [59-61]. For these reasons, we focused our attention on the TUs encoding pre-miRNAs, to test the possibility that ER $\beta$ binding sites might be located in close proximity of these genes. Results show that 52 miRNA-encoding loci (isolated or in genomic clusters) show one or more ER $\beta$ site within $10 \mathrm{~kb}$ from the pre-miR sequence of the host gene - listed in Additional Table S7 [Additional file 6]. Distribution of these sites among the ER binding Classes described above was comparable to what observed for primary genes. Interestingly, in several cases ER $\beta$ binds both up- and down-stream of the pre-miR locus, further suggesting that receptor docking might exert multiple regulatory actions on miRNA biogenesis.

We tested the hypothesis that the observed distribution of sites near the pre-miRNA loci occurred at random by applying a bootstrap approach. To this end, we repeatedly sampled 1000 times the same number of sites of the real ER $\beta$ binding set, with the same length distribution, a similar distribution among chromosomes but randomly selected coordinates. We then counted the number of pre-miRNA loci and the number of randomly generated sites found within $10 \mathrm{~kb}$ of each other and compared their distributions with that of the experimentally detected ones. The number of randomly generated sites within $10 \mathrm{~kb}$ of a pre-miRNA never reached the value detected experimentally, while the number of miRNA loci scoring an artificial site in close proximity was equal or above what measured only in $7.6 \%$ of the cases. These results can be explained also by the observation that in several cases ER $\beta$ binds both up- and down-stream of the pre-miR locus, a result that support a functional significance of this observation. In fact, the ratio between the number of ER $\beta$ binding sites and the number of pre-miRNA loci within $10 \mathrm{~kb}$ of each other is 1.5 , while this varied between 0.5 and 1 for the randomly generated sets (data not shown). We thus conclude that although some of the ER $\beta$ sites detected in or near pre-miRNA loci may be the result of a random, non functional event, these is likely to represent rare events, as random distribution never reaches the enrichment level observed experimentally. Indeed, preliminary miRNA profiling analyses carried out in $w t$ MCF-7 and TAP-ER $\beta$ cells indicate that mature miRNA expression undergo extensive deregulation in the presence of ER $\beta$ [O. Paris et al., manuscript in preparation and data not shown], suggesting that at least some of the sites identified here might indeed be involved in ER $\beta$-mediated regulation of miRNA biosynthesis in BC cells.

\section{ER $\beta$ binding to the mitochondrial genome}

Mitochondrial DNA (mtDNA) is usually overlooked in whole-genome ChIP-seq analyses, since identification of enriched peaks is more difficult here due to a much higher noise, consequence of the high and variable number of mtDNA copies in the cell. ER $\beta$ has been shown to localize in the mitochondria in different cell types [62] including human BC cells [63,64], and a role for estrogen in mitochondrial function, with implications on cell growth, has been established $[65,66]$. We thus analyzed the sequence reads that aligned on the mtDNA sequence with the same method used for whole genome data analysis, but applying a supplementary fold-intensity filter (see Methods) to deal with the higher background noise. This analysis revealed one ER $\beta$ binding site in proximity of the mtDNA D-loop, but no ER $\alpha$ binding sites either in $w t$ MCF-7 or in TAP-ER $\beta$ cells (Figure 5A). Independent ChIP analysis confirmed this results, showing ER $\beta$ binding to this same mtDNA region upon activation by E2 or its selective agonist 2,3bis(4-hydroxyphenyl) propionitrile (DPN) and lack of $\mathrm{ER} \alpha$ binding (Figure 5B). Furthermore, the presence of ER $\beta$ in mitochondria of TAP-ER $\beta$ cells was confirmed biochemically, by western blotting (Figure $5 \mathrm{C}$ ), an analysis that revealed also the presence of ER $\alpha$ in the organelle. When we analyzed the sequence of the ER $\beta$ mitochondrial site with MatInspector, we observed the presence of the matrix V\$GATA1.06, bound by GATA1, a factor whose activity is strongly repressed by ER $\alpha$ [67], and V\$HMGA.01, bound by HMGA1, a non-histone chromosomal protein that is highly overexpressed in cancer cells [68] and has been shown to interact with $\mathrm{ER} \alpha$ and to enhance its binding to DNA [69].

\section{Conclusions}

The results of this study indicate that in vivo ER $\beta$ can interact with hormone-responsive $\mathrm{BC}$ cell chromatin either alone or complexed with ER $\alpha$, but in all cases the two receptors share the same genomic targets. An 


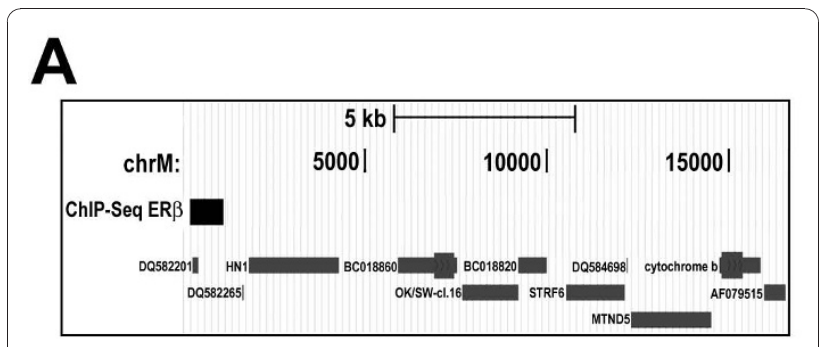

B

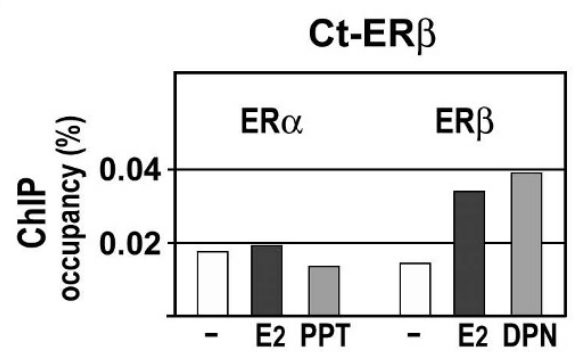

C

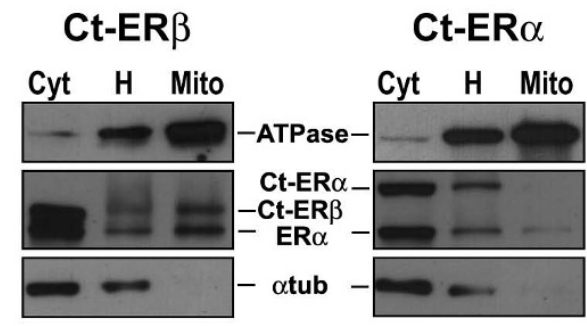

Figure 5 Mitochondrial ER-beta binding sites. (A) Genome Browser view of the ER $\beta$ binding site identified in mitochondrial genome. (B) Validation of ER $\beta$ binding to mitochondrial DNA by ChIP. Results shown are representative of duplicate analyses. E2: $10^{-8} \mathrm{M} 17 \beta$-estradiol; PPT: $10^{-8} \mathrm{M}$ 1,3,5-tris(4-hydroxyphenyl)-4-propyl$1 \mathrm{H}$-pyrazole (selective ER $\alpha$ agonist); DPN: $10^{-8} \mathrm{M}$ 2,3-bis(4hydroxyphenyl) propionitrile (ER $\beta$ agonist). (C) Western blot analysis of ER $\beta$ and/or ER $\alpha$ in purified mitochondria from Ct-ER $\beta$ and Ct-ER $\alpha$ [33] cells. Cyt: cytosol depleted of mitochondria, H: whole cell homogenate; Mito: purified mitochondrial fraction. ATPase is a mitochondrial marker and $\alpha$-tubulin was included to determine the level cytosolic contaminants in 'Mito' samples.

observation that is in agreement with the conclusions of previous studies based on analysis of ER $\alpha$ and ER $\beta$ heterodimerization and binding to the ERE [9,70-72]. When both ER subtypes are expressed in the same cell, the main action of ER $\beta$ in the genome is thus achieved in combination with $\mathrm{ER} \alpha$, by either heterodimerization or competition for binding to the same target sites in chromatin. Based on these observations, we propose that in hormoneresponsive $\mathrm{BC}$ the final cellular response to estrogen is likely to depend upon the relative concentration of the two ERs in the cell, their activation status and DNA binding kinetics and the presence of other factors influencing their respective functions.

\section{Methods}

Plasmid preparation, cell lines, cell culture and stable transfections

Different BC cell lines were used: MCF-7 TET Off (ERalpha positive; ATCC, Cat No. HTB-22) and SKBR3 (ER-alpha negative; ATCC, Cat No. HTB-30). MCF-7 TET Off cells (described here as $w t$ or ER $\beta$-) were used to produce stable clones expressing ER $\beta$ tagged with TAP-tag respectively at the $\mathrm{C}$-term and at the $\mathrm{N}$-term (Ct-ER $\beta$ and Nt-ER $\beta$ ) or C-tagged ER $\alpha$ (Ct-ER $\alpha$ ), as previously described [5,33]. All were grown in Dulbecco's modified Eagle's medium (DMEM), supplemented with $10 \%$ fetal bovine serum (FBS) (both from Invitrogen), $100 \mathrm{U} / \mathrm{ml}$ penicillin, $100 \mathrm{mg} / \mathrm{ml}$ streptomycin, 250 ng/ml Amfotericin-B, $50 \mu \mathrm{g} / \mathrm{ml} \mathrm{G418} \mathrm{(normal} \mathrm{growing}$ condition). For estrogen starvation, cells were plated at $40 \%$ confluence in steroid-free medium (phenol red-free DMEM medium, with $5 \%$ fetal bovine serum pre-treated with dextran-coated charcoal and antibiotics) and maintained for 5 days with replacement of fresh medium before stimulation with $10^{-8} \mathrm{M} 17 \beta$-estradiol (E2).

\section{Preparation of cell extracts, mitochondria isolation and immunoblotting analyses}

Cells starved in 100-mm dishes were stimulated for 45 minutes, harvested in cold PBS and collected by centrifugation at $1000 \times \mathrm{g}$. The cell pellets were then resuspended in three volumes of Hypotonic Buffer (HB) (20 $\mathrm{mM}$ HEPES pH 7.4, $5 \mathrm{mM}$ Sodium Fluoride, $10 \mu \mathrm{M}$ Sodium Molybdate, $0.1 \mathrm{mM}$ EDTA, $1 \mathrm{mM}$ dithiothreitol, $1 \mathrm{mM}$ protease inhibitors, $1 \mathrm{mM}$ Phenylmethyl-Sulfonyl Fluoride). Cells were then incubated on ice for $15 \mathrm{~min}$ and $0.5 \%$ Nonidet P-40 followed by spinning $30 \mathrm{sec}$ at $4^{\circ} \mathrm{C}$ at $13000 \times \mathrm{g}$. Supernatants were recovered and clarified at $13,000 \times \mathrm{g}$ for $15 \mathrm{~min}$ at $4^{\circ} \mathrm{C}$ while pellets were resuspended in hypotonic buffer, stratified on $25 \%$ sucrose-HB solution and centrifuged at $6000 \times \mathrm{g}$ for 15 $\min$ at $4^{\circ} \mathrm{C}$. The resulting pellets were then resuspended in one volume of Nuclear Lysis Buffer [73] containing $800 \mathrm{mM} \mathrm{NaCl}$, incubated for $30 \mathrm{~min}$ at $4^{\circ} \mathrm{C}$ with gentle shaking and centrifuged for $15 \mathrm{~min}$ at $4^{\circ} \mathrm{C}$ at $13000 \times \mathrm{g}$. The supernatant fraction was recovered.

Mitochondria were isolated from $20 \times 10^{6} \mathrm{Ct}$-ER $\beta$ or Ct-ER $\alpha$ cells (in $150 \mathrm{~mm}$ culture dishes) as described [74], with minor modifications. All steps during mitochondria isolation were performed at $4^{\circ} \mathrm{C}$, cells were washed twice in PBS, scraped, and centrifuged at $290 \times$ g, 5 minutes. The samples were resuspended in buffer A $(250 \mathrm{mM}$ Sucrose, $50 \mathrm{mM}$ Tris- $\mathrm{HCl}, 2 \mathrm{mM}$ EGTA), homogenized in Glass-Teflon Potter homogenizer and centrifuged at $600 \times$ $\mathrm{g}$ for $3 \mathrm{~min}$, then the supernatants were re-centrifuged at the same speed. Mitochondria were pelleted by centrifugation at $10400 \times \mathrm{g}$ for $10 \mathrm{~min}$, resuspended in buffer $\mathrm{A}$ and centrifuged again at $5300 \times \mathrm{g}$ for $10 \mathrm{~min}$, in order to 
eliminate microsomal and cytosolic contamination. The samples were dissolved in buffer $\mathrm{A}$ and centrifuged at $1500 \times \mathrm{g}$ for $4 \mathrm{~min}$ and then pelleted again at $9600 \times \mathrm{g}$ for 10 minutes. The final pellet was resuspended in Buffer B (50 mM Tris pH 7.5, $150 \mathrm{mM} \mathrm{NaCl,} \mathrm{1 \%} \mathrm{Triton} \mathrm{X-100,}$ $0.1 \%$ SDS, $1 \%$ Na Deoxycholate, $1 \mathrm{mM}$ PMSF, $1 \mathrm{X}$ Protease Inhibitor) and incubated on ice for $20 \mathrm{~min}$ to extract mitochondrial proteins. A small portion of sample was collected after homogenization and processed to obtain the samples corresponding to homogenate and cytosol. An equivalent protein amount was fractionated by SDS-PAGE on Mini Protean Precast polyacrylamide gels 4-20\% from Biorad.

Homogenate, cytosol, nuclear or mitochondrial extracts from equivalent cell number were fractionated by SDS-PAGE. Immunoblot analysis was performed using the following primary antibodies: Ct-ER $\alpha$ (HC-20; sc-543) from Santa Cruz Biotechnology, Inc., TAP tag (CAB1001) from Open Biosystems, $\alpha$-Tubulin ( $T$ 6199) from Sigma-Aldrich, ATPase B (ab14730) from Abcam. Peroxidase-labelled anti-rabbit or -mouse immunoglobulin antisera were used according to the manufacturer's instructions (Amersham Italia).

\section{Transient Transfections and Luciferase Assay}

Wild type MCF-7, Ct-ER $\beta$ and Nt-ER $\beta$ clones were starved for 5 days in estrogen-free medium. Then $5 \times$ $10^{5}$ cells/dish were seeded in $60 \mathrm{~mm}$ culture dishes and transfected by using $25 \mu \mathrm{g} /$ dish polyethylenimine (Polysciences, Inc.) with $2.5 \mu \mathrm{g} /$ dish DNA, including $300 \mathrm{ng}$ ERE-tk-Luc [75], 500 ng pSG- $\Delta 2-N L S-L a c Z$ vector [76], co-transfected as an internal control for transfer efficiency, and carrier DNA (Bluescribe M13+). At 48 hrs after transfection, cells were treated for 24 hrs with either vehicle $(\mathrm{EtOH})$ or E2 $\left(10^{-8} \mathrm{M}\right)$.

SKBR3 cells were grown to $60-70 \%$ confluence and transfected with Lipofectamine 2000 reagent (Invitrogen) and OPTI-MEM (Invitrogen) according to the manufacturer's instructions. The plasmids used were pSG5-ER $\beta$, encoding full-length ER $\beta$ (ER $\beta 1)$, pSGHEGO, encoding the full-length ER $\alpha$ and the corresponding pSG5 empty vector (Stratagene), pUSE-CTAP-ER $\beta$ and pUSE-N-TAP-ER $\beta$, encoding full-length ER $\beta$ tagged, respectively, at the C-term and at the $\mathrm{N}$ term [5], ERE- $t k$-Luc and pSG- $\Delta 2$-NLS-LacZ. Six hours after transfection, the medium was changed and $24 \mathrm{hrs}$ later cells were stimulated as described above for $24 \mathrm{hrs}$. At the end of treatment, cells were washed with cold PBS and lysed in $100 \mu$ l lysis buffer (Promega). Luciferase activity was measured in extracts using the Luciferase Assay Reagent (Promega), according to the manufacturer's instructions, and values were expressed as relative light units normalized to the $\beta$-galactosidase activity or to the protein concentrations measured using the Bradford technique. For each condition, average luciferase activity was calculated from the data obtained from three independent dishes.

\section{Cell Cycle Analysis}

Estrogen-deprivation was always controlled by cell cycle analysis as follows. Cells $\left(1.5 \times 10^{5}\right.$ cells/dish $)$ were starved in $60 \mathrm{~mm}$ culture dishes, stimulated for $27 \mathrm{hrs}$ and collected in PBS containing $50 \mu \mathrm{g} / \mathrm{ml}$ propidium iodide, $0.1 \%(\mathrm{v} / \mathrm{v})$ sodium citrate, $0.1 \%(\mathrm{v} / \mathrm{v})$ Nonidet P40. Cell samples were incubated in the dark for at least $15 \mathrm{~min}$ at room temperature, or overnight at $4^{\circ} \mathrm{C}$, and analyzed by a FACScalibur flow cytometer using the CellQuest software package (BD Biosciences), according to standard protocols suggested by the manufacturer $[77,78]$. Data analysis was performed with Modfit software (Verity Software, Topsham). Values were plotted as increasing of S-phase respect to unstimulated controls. Results showed were obtained from two independent experiments.

\section{Cell Proliferation Assay}

Hormone-starved cells (3000/well) were seeded in 96well dishes. After 12 hrs, medium was changed to include the indicated compounds. After appropriate stimulation, cells were washed in phosphate-buffered saline (PBS) and fixed with 12.5\% glutaraldehyde for 20 min at room temperature, followed by washing with distilled water, incubation with $0.05 \%$ methylene blue for $30 \mathrm{~min}$, rinsing and incubation with $0.33 \mathrm{M} \mathrm{HCl}$ for 18 hrs. Absorption was measured at $620 \mathrm{~nm}$.

\section{RNA purification}

Total RNA was extracted from wt MCF-7, Ct-ER $\beta$ and $\mathrm{Nt}$-ER $\beta$ clones, generated as described above, using the standard RNA Extraction method with TRIzol (Invitrogen) method, as described previously $[79,80]$. Cells were estrogen-deprived and total RNA was extracted before or at the indicated times after stimulation with $10^{-8} \mathrm{M}$ $17 \beta$-estradiol (+E2) or ethanol vehicle.

In each case RNA derived from two independent experiments performed in duplicate was used. Before use, RNA concentration in each sample was assayed with a ND-1000 spectrophotometer (NanoDrop) and its quality assessed with the Agilent 2100 Bioanalyzer with Agilent RNA 6000 nanokit (Agilent Technologies).

\section{Microarray analyses}

Total RNA extracted from Ct-ER $\beta$ and Nt-ER $\beta$ cells were pooled. For mRNA expression profiling, $500 \mathrm{ng}$ total RNA were reverse transcribed, as described previously $[26,81]$ and used for synthesis of cDNA and biotinylated cRNA according to the Illumina TotalPrep RNA Amplification Kit (Ambion, Cat. n. IL1791) 
protocol. For each sample, $750 \mathrm{ng}$ of cRNA were hybridized for $18 \mathrm{hrs}$ at $55^{\circ} \mathrm{C}$ on Illumina HumanHT-12 v3.0 BeadChips, containing 48,804 probes (Illumina Inc.), according to the manufacturer's protocol and subsequently scanned with the Illumina BeadArray Reader 500. Data analyses were performed with GenomeStudio software version 2009 (Illumina Inc.), by comparing all values obtained at each time point against the $0 \mathrm{hrs}$ values. Data was normalized with the quantile normalization algorithm, and genes were considered as detected if the detection p-value was lower than 0.01. Statistical significance was calculated with the Illumina DiffScore, a proprietary algorithm that uses the bead standard deviation to build an error model. Only genes with a DiffScore $\leq-40$ and $\geq 40$, corresponding to a $p$-value of 0.0001 , were considered as statistical significant.

\section{Chromatin Immunoprecipitation}

Ct-ER $\beta$ and Nt-ER $\beta$ cells were hormone-deprived for 4 days and chromatin was extracted in several replicates before (-E2) and after stimulation for 45 minutes with $10^{-8} \mathrm{M} 17 \beta$-estradiol (+E2) or, where indicated, with the $10^{-8} \mathrm{M}$ selective ER $\alpha$ agonist 1,3,5-tris(4-hydroxyphenyl)4-propyl-1H-pyrazole (PPT) or $10^{-8} \mathrm{M}$ ER $\beta$ agonist 2,3-bis (4-hydroxyphenyl) propionitrile (DPN), from Tocris Cookson.

Chromatin was prepared with the Millipore/Upstate Chromatin Immunoprecipitation (ChIP) Assay Kit (Millipore) according to the instruction provided by the producer, using a variation of the protocol described at the Upstate website. For each assay, a total of $5 \times 10^{6}$ cells were fixed with $1 \%$ formaldeyde for $10 \mathrm{~min}$ at room temperature, the reaction was then stopped by adding glycine at final concentration of $0.125 \mathrm{M}$. Fixed cells were washed twice with ice-cold PBS, harvested by scraping, centrifuged and the cell pellets were re-suspended in SDS lysis buffer. Samples were sonicated with a Diagenode Bioruptor (Diagenode) for 12 cycles of 30 $\mathrm{sec}$ at high power, centrifuged at $12500 \mathrm{xg}$ for $15 \mathrm{~min}$ utes and diluted 8-fold in ChIP dilution buffer. After removing an aliquot (whole-cell extract input), the chromatin sample was divided in three aliquots, that were incubated at $4^{\circ} \mathrm{C}$ overnight with antibodies against either the C-term (HC-20, from Santa Cruz Biotechnology) or N-term (anti-Estrogen Receptor 18-32, from SigmaAldrich) of human ER $\alpha$ or with IgG Sepharose 6 fast Flow (GE Healthcare Bio-Science AB) for TAP-ER $\beta$ [5]. As control, an aliquot of the same chromatins were processed in the same way but Abs or IgGs were omitted form the reaction. The samples were then precipitated by binding to protein-A Agarose/Salmon Sperm DNA beads (Millipore), for ER $\alpha$, or as such for to ER $\beta$. The beads were washed sequentially with 'low-salt immune complex wash buffer, 'high salt immune complex wash buffer, 'LiCl immune complex wash buffer' and TE buffer, before elution in Elution buffer by $\mathrm{ON}$ incubation at $65^{\circ} \mathrm{C}$ and treatment with Proteinase K. DNA was purified from immunoprecipitated (IPP) chromatin by extraction with phenol:chloroform:isoamyl alcohol (25:24:1) and ethanol precipitation according to standard procedures. DNA pellets were dissolved in nuclease-free water and kept frozen before further use.

Primers for ChIP-QPCR validation of the mitochondrial genome ER $\beta$ binding site were the following: 5'GATCACAGGTCTATCACCCTATTAACC (forward) and 5'-CAGCGTCTCGCAATGCTATC (reverse).

\section{Samples preparation for ChIP-Seq}

DNAs from Ct-ER $\beta$ and Nt-ER $\beta$ cells treated with E2 were pooled together to generate an ER $\beta+\mathrm{E} 2$ sample and the same was done for DNAs from hormone-starved cells (ER $\beta$-E2 sample). Similarly, IPP DNAs obtained with anti-C-term and anti-N-term $\mathrm{ER} \alpha \mathrm{Abs}$ were pooled together to generate $\mathrm{ER} \alpha+\mathrm{E} 2$ and $\mathrm{ER} \alpha-\mathrm{E} 2$ samples. About $20 \mathrm{ng}$ of ChIP DNA was purified using the MinElute PCR Purification Kit (QIAGEN, Italy), with a recovery of 55-70\%, as assessed with the Quant-IT DNA Assay Kit-High Sensitivity and a Qubit Fluorometer (Invitrogen). Preparation of IPP DNA libraries for massively parallel sequencing was performed from $10 \mathrm{ng}$ purified DNA according to the Illumina ChIP-Seq sample preparation kit protocol (Illumina Inc.). Libraries were sequenced with the Illumina Cluster Station and Genome Analyzer II according to manufacturer's instructions.

\section{ChIP-Seq data analysis}

The sequence tags generated by massively parallel sequencing were aligned on the human genome (hg18) with the software ELAND, allowing up to 2 mismatches. Enriched regions from $\mathrm{ER} \alpha+\mathrm{E} 2$ and $\mathrm{ER} \beta+\mathrm{E} 2$ samples were compared with the same from ER $\alpha-E 2$ and ER $\beta$ -E2 samples, respectively. The enriched ChIP-Seq peaks were identified using MACS (Model-based Analysis of ChIP-Seq) version 1.3.7.1 [39], with standard parameters (p-value cut-off of 1e-5, mfold of 32). For mtDNA we further filtered out sites with tag density below $0.5(\mathrm{~N} / \mathrm{l}$; $\mathrm{N}=$ number of tags, 1 = length of site)

\section{Computational searches for ERE sequences}

The ERE binding motif was searched in binding sites with the MatInspector application [82], a part of GenomatixSuite software (Genomatix Software GmbH, Germany). The matrices ER.01, ER.02, ER.03 and ER.04 (Genomatix Matrix Library 8.2), were used with a core similarity threshold of 0.75 and a matrix similarity threshold of Optimal -0.02. The sequences bearing a match of any of the four matrices were termed ERE+ sequences. On the remaining sequences, the hemi-palindromic ERE 
motif was searched with the same application, by defining a custom half ERE matrix PuGGTCA (hERE). The remaining sequences were classified as ERE- and were scanned for other TF binding sites motifs contained in the Genomatix Matrix Library using the standard parameters, as described previously [26].

\section{TFBS over-representation analysis}

ERE- sequences were analyzed to search for known TF binding sites (TFBSs) that were enriched (over-represented) with respect to their relative frequency in the whole human genome. This analysis was performed with the RegionMiner application of the Genomatix software suite [47]. The software automatically searches for all TFBS matches present in the submitted sequence list and calculates the over-representation value of the actual number of matches over the expected value based on its frequency in the reference set (genome or promoters) for each matrix. It reports also the significance of the overrepresentation ratio, expressed as Z-scores [83]. Enrichment values with a $\mathrm{Z}$-score $<3.0$ were not considered further. A filter was applied also on the over-representation values, depending upon the range of values set for each analysis, to highlight only the stronger associations. Results are shown as heatmaps representing over-representation values, generated with $\mathrm{MeV}$ software [84].

\section{Classification of ER $\beta$ binding sites and identification of primary ER $\beta$ responsive genes by combining ChIP-Seq and expression profiling data}

Three sets of ER binding sites were taken in consideration. The first and second comprised, respectively, the ER $\beta$ and ER $\alpha$ sites mapped in TAP-ER $\beta$ cells and the third (named 'MCF-7 ER $\alpha$ ') included all ER $\alpha$ binding sites identified in $w t$ MCF-7 cells by ChIP-Seq $[26,27]$ and/or by ChIP-onchip [28]. First of all, the ER binding sites from ChIP-Seq analyses were elongated in both directions by $1000 \mathrm{bp}$. Subsequently, using UCSC Table Browser [85], for each of the first two sets the extended sites overlapping with each other were merged in ER $\beta$ or ER $\alpha$ binding 'regions', respectively. For the third set ( $w t$ MCF-7 ER $\alpha$ ), the extended ChIP-Seq sites and the ChIP-on-chip sites overlapping with each other in the genome were all merged to generate unique MCF-7 ER $\alpha$ binding 'regions'. To identify putative primary ER $\beta$ responsive genes, the TUs corresponding to RNAs differentially regulated by E2 in ER $\beta+$ vs ER $\beta$ - cells that showed one or more ER $\beta$ binding region inside or within $10 \mathrm{~kb}$ were extracted using UCSC Table Browser, as described previously [26].

\section{Gene Ontology analysis}

To identify Biological Process GO terms statistically overrepresented in our regulated gene lists, we used Ontologizer 2.0, a tool for GO term enrichment analysis of genes derived from an experiment [52]. We identified enriched terms in primary ER $\beta$ or ER $\alpha$ target genes against all genes expressed (detected) in the cell lines under study, set as background of the analysis, with a $p$ value threshold of 0.01 .

\section{Microarray and ChIP-Seq data accession numbers}

The microarray and ChIP-Seq data have been deposited in the Array Express database ( HYPERLINK "http:// www.ebi.ac.uk/arrayexpress" http://www.ebi.ac.uk/ arrayexpress) with Accession Numbers E-TABM-1051 and E-MTAB-345, respectively.

\section{Additional material}

Additional File 1: Grober_ER-alpha_Binding_Sites ER $\alpha$ binding sites. The UCSC genome BED formatted file lists the chromosome, start coordinate, stop coordinate and identifier of the ERo binding sites.

Additional File 2: Grober_ER-beta_Binding_Sites ER $\beta$ binding sites. The UCSC genome BED formatted lists the chromosome, start coordinate, stop coordinate and identifier of the ER $\beta$ binding sites.

Additional File 3: Sheet 1: Additional Table S1 Differentially Regulated Genes. Overview of the 921 genes differentially regulated by $E 2$ in ER $\beta+v s$ ER $\beta$ - cells, containing the following additional information: gene set membership, symbol, Entrez ID, gene name and expression values (fold-change). Sheet 2: Additional Table S2 TFBS enrichment matrix. The worksheet shows the over-representation values for the TF binding matrices from ERE- binding sites. Sheet 3: Additional Table S3 Primary ER $\beta$ target genes, showing ER $\beta$ binding sites within $10 \mathrm{~kb}$ of the TU. Overview of the 424 putative ER $\beta$ primary gene targets containing the following additional information: gene set membership, category of ERB binding sites, Symbol, Entrez ID, Gene Name, TU Coordinates, ERo Binding Sites Coordinates and ER $\beta$ Binding Sites Coordinates. Sheet 4: Additional Table S4 Primary ER $\alpha$ target genes, showing ER $\alpha$ binding sites within $10 \mathrm{~kb}$ of the TU in ERß-cells. Overview of the 228 putative ER $\alpha$ primary gene targets containing the following additional information: Symbol, Entrez ID, Gene Name, TU Coordinates.

\section{Additional File 4: GO analysis of primary ER $\beta$ target genes.}

Containing the following information: Biological process, Gene Ontology term, Name, Count in total GO population, Count in selected genes, \% genes and $p$-value.

Additional File 5: $\mathrm{GO}$ analysis of primary $\mathrm{ER} \alpha$ target genes.

Containing the following information: Biological process, Gene Ontology term, Name, Count in total GO population, Count in selected genes, \% genes and $p$-value.

Additional File 6: ER $\beta$ binding sites in proximity of miRNA loci. Containing the following information: miRNA name, ID of ER- $\beta$ binding site upstream, Distance from the closest ER $\beta$ binding site upstream, ID of ER- $\beta$ binding site downstream and Distance from the closest ER $\beta$ binding site downstream.

\section{Acknowledgements}

Work supported by the European Union (CRESCENDO I.P., contract n.er LSHM-CT2005-018652), the Italian Association for Cancer Research (grant IG8586) and the Italian Ministry for Education, University and Research (grant PRIN 2008CJ4SYW_004), Fondazione per il Sud (grant 2009-PdP-22) to AW. MR, GN and RT are recipient of fellowships from Fondazione per il Sud. The authors thank Dr Rosario Casale for technical assistance and Francesca Rizzo for revision of the manuscript.

\section{Author details}

'Department of General Pathology, Second University of Naples, vico L. De Crecchio 7, 80138 Napoli, Italy. ${ }^{2}$ Molecular Medicine Laboratory, University of 
Salerno, via Allende, 84081 Baronissi, Italy. ${ }^{3}$ Illumina, Inc., Hayward, 94545 California, USA. ${ }^{4}$ Genomics Core Facility, European Molecular Biology Laboratory, Heidelberg 69117, Germany.

\section{Authors' contributions}

OMVG, MM, GG, MR, LC, MRDF, LF, GN, MFP, OP and RT participated in the conception and design of the study, performed in vivo and in vitro experimental work (OP, GN, MFP, RT), statistical and in silico data analyses (OMVG, MM, GG, MRDF) and participated in drafting the manuscript. OP, LC and MR prepared and tested the sequencing libraries. LC, LF and MR carried out the microarray experiments and participated in data analyses. SL, GPS and VB participated in the conception and design of the study and performed massively parallel sequencing. AW coordinated the project, participated in conception and design of the study and participated in drafting and finalization of the manuscript. All authors read and approved the final manuscript.

\section{Competing interests}

The authors declare that they have no competing interests.

Received: 23 August 2010 Accepted: 14 January 2011

Published: 14 January 2011

\section{References}

1. Heldring N, Pike A, Andersson S, Matthews J, Cheng G, Hartman J, Tujague M, Strom A, Treuter E, Warner M, Gustafsson JA: Estrogen receptors: how do they signal and what are their targets. Physiol Rev 2007, 87:905-931.

2. Hall JM, Couse JF, Korach KS: The multifaceted mechanisms of estradiol and estrogen receptor signaling. J Biol Chem 2001, 276:36869-36872.

3. Bai Z, Gust R: Breast cancer, estrogen receptor and ligands. Arch Pharm (Weinheim) 2009, 342:133-149.

4. Ordonez-Moran P, Munoz A: Nuclear receptors: genomic and nongenomic effects converge. Cell Cycle 2009, 8:1675-1680.

5. Nassa G, Tarallo R, Ambrosino C, Bamundo A, Ferraro L, Paris O, Ravo M, Guzzi PH, Cannataro M, Baumann M, Nyman TA, Nola E, Weisz A: A large set of estrogen receptor beta-interacting proteins identified by tandem affinity purification in hormoneresponsive human breast cancer cell nuclei. Proteomics.

6. Tarallo R, Bamundo A, Nassa G, Nola E, Paris O, Ambrosino C, Facchiano A, Baumann M, Nyman TA, Weisz A: Identification of proteins associated with ligand-activated estrogen receptor alpha in human breast cancer cell nuclei by tandem affinity purification and nanoLC-MS/MS. Proteomics.

7. Matthews J, Gustafsson JA: Estrogen signaling: a subtle balance between ER alpha and ER beta. Mol Interv 2003, 3:281-292.

8. Klinge CM, Jernigan SC, Mattingly KA, Risinger KE, Zhang J: Estrogen response element-dependent regulation of transcriptional activation of estrogen receptors alpha and beta by coactivators and corepressors. J Mol Endocrinol 2004, 33:387-410.

9. Cowley SM, Hoare S, Mosselman S, Parker MG: Estrogen receptors alpha and beta form heterodimers on DNA. J Biol Chem 1997, 272:19858-19862.

10. Zhao C, Matthews J, Tujague M, Wan J, Strom A, Toresson G, Lam EW, Cheng G, Gustafsson JA, Dahlman-Wright K: Estrogen receptor beta2 negatively regulates the transactivation of estrogen receptor alpha in human breast cancer cells. Cancer Res 2007, 67:3955-3962.

11. Nassa G, Tarallo R, Guzzi PH, Ferraro L, Cirillo F, Ravo M, Nola E, Baumann M, Nyman TA, Cannataro M, Ambrosino C, Weisz A: Comparative analysis of nuclear estrogen receptor alpha and beta interactomes in breast cancer cells. Mol BioSyst 2010.

12. Matthews J, Wihlén B, Tujague M, Wan J, Ström A, Gustafsson JA: Estrogen receptor (ER) beta modulates ERalpha-mediated transcriptional activation by altering the recruitment of c-Fos and c-Jun to estrogenresponsive promoters. Mol Endocrinol 2006, 20:534-43.

13. Katzenellenbogen BS, Montano MM, Ediger TR, Sun J, Ekena K, Lazennec G, Martini PG, Mclnerney EM, Delage-Mourroux R, Weis K, Katzenellenbogen JA: Estrogen receptors: selective ligands, partners, and distinctive pharmacology. Recent Prog Horm Res 2000, 55:163-93.

14. Pettersson K, Delaunay F, Gustafsson JA: Estrogen receptor beta acts as a dominant regulator of estrogen signaling. Oncogene 2000, 19:4970-4978.

15. Sugiura H, Toyama T, Hara Y, Zhang Z, Kobayashi S, Fujii Y, Iwase H, Yamashita $\mathrm{H}$ : Expression of estrogen receptor beta wild-type and its variant ERbetacx/beta2 is correlated with better prognosis in breast cancer. Jpn J Clin Oncol 2007, 37:820-828.

16. Saji S, Hirose M, Toi M: Clinical significance of estrogen receptor $\beta$ in breast cancer. Cancer Chemother Pharmacol 2005, 56(Suppl 1):21-26.

17. Lindberg MK: Estrogen Receptor (ER)-beta Reduces ERalpha-Regulated Gene Transcription, Supporting a "Ying Yang" Relationship between ERalpha and ERbeta in Mice. Mol Endocrinol 2003, 17:203-208.

18. Lazennec G, Bresson D, Lucas A, Chauveau C, Vignon F: ER beta Inhibits Proliferation and Invasion of Breast Cancer Cells. Endocrinology 2001, 142:4120-4130.

19. Behrens D, Gill JH, Fichtner I: Loss of tumourigenicity of stably ERbetatransfected MCF-7 breast cancer cells. Mol Cell Endocrinol 2007, 274:19-29.

20. Paruthiyil S, Parmar H, Kerekatte V, Cunha GR, Firestone GL, Leitman DC: Estrogen Receptor Inhibits Human Breast Cancer Cell Proliferation and Tumor Formation by Causing a G2 Cell Cycle Arrest. Cancer Res 2004, 64:423-428.

21. Chang EC, Frasor J, Komm B, Katzenellenbogen BS: Impact of estrogen receptor beta on gene networks regulated by estrogen receptor alpha in breast cancer cells. Endocrinology 2006, 147:4831-4842.

22. Lin CY, Ström A, Li Kong S, Kietz S, Thomsen JS, Tee JB, Vega VB, Miller LD, Smeds J, Bergh J, Gustafsson JA, Liu ET: Inhibitory effects of estrogen receptor beta on specific hormone-responsive gene expression and association with disease outcome in primary breast cancer. Breast Cancer Res 2007, 9:R25.

23. Williams C, Edvardsson K, Lewandowski SA, Ström A, Gustafsson J: A genome-wide study of the repressive effects of estrogen receptor beta on estrogen receptor alpha signaling in breast cancer cells. Oncogene 2008, 27:1019-1032.

24. Fritzemeier $\mathrm{KH}$, Hillisch $\mathrm{A}$, Elger $\mathrm{W}$, Kaufmann $\mathrm{U}$, Kollenkirchen $\mathrm{U}$, Kosemund D, Lindenthal B, Müller G, Muhn P, Nubbemeyer R, Peters O, Siebel P, Hegele-Hartung C: Biological effects of ERalpha- and ERbetaselective estrogens. Ernst Schering Res Found Workshop 2004, 46:127-150.

25. Carroll JS, Liu XS, Brodsky AS, Li W, Meyer CA, Szary AJ, Eeckhoute J, Shao W, Hestermann EV, Geistlinger TR, Fox EA, Silver PA, Brown M: Chromosome-wide mapping of estrogen receptor binding reveals longrange regulation requiring the forkhead protein FoxA1. Cell 2005, 122:33-43.

26. Cicatiello L, Mutarelli M, Grober OM, Paris O, Ferraro L, Ravo M, Tarallo R, Luo S, Schroth GP, Seifert M, Zinser C, Chiusano ML, Traini A, De Bortoli M, Weisz A: Estrogen Receptor alpha Controls a Gene Network in LuminalLike Breast Cancer Cells Comprising Multiple Transcription Factors and MicroRNAs. Am J Pathol 2010, 176:2113-2130.

27. Fullwood MJ, Liu MH, Pan YF, Liu J, Xu H, Mohamed YB, Orlov YL, Velkov S, Ho A, Mei PH, Chew EG, Huang PY, Welboren WJ, Han Y, Ooi HS, Ariyaratne PN, Vega VB, Luo Y, Tan PY, Choy PY, Wansa KD, Zhao B, Lim KS, Leow SC, Yow JS, Joseph R, Li H, Desai KV, Thomsen JS, Lee YK, Karuturi RK, Herve T, Bourque G, Stunnenberg HG, Ruan X, Cacheux-Rataboul V, Sung WK, Liu ET, Wei CL, Cheung E, Ruan Y: An oestrogen-receptor-alphabound human chromatin interactome. Nature 2009, 462:58-64.

28. Hurtado A, Holmes KA, Geistlinger TR, Hutcheson IR, Nicholson RI, Brown M, Jiang J, Howat WJ, Ali S, Carroll JS: Regulation of ERBB2 by oestrogen receptor-PAX2 determines response to tamoxifen. Nature 2008, 456:663-666.

29. Vivar Ol, Zhao X, Saunier EF, Griffin C, Mayba OS, Tagliaferri M, Cohen I, Speed TP, Leitman DC: Estrogen receptor beta binds to and regulates three distinct classes of target genes. J Biol Chem 2010, 285:22059-22066.

30. Charn TH, Liu ET, Chang EC, Lee YK, Katzenellenbogen JA, Katzenellenbogen BS: Genome-wide dynamics of chromatin binding of estrogen receptors alpha and beta: mutual restriction and competitive site selection. Mol Endocrinol 2010, 24:47-59.

31. Zhao C, Gao H, Liu Y, Papoutsi Z, Jaffrey S, Gustafsson JA, DahlmanWright K: Genome-wide mapping of estrogen receptor-beta-binding regions reveals extensive cross-talk with transcription factor activator protein-1. Cancer Res 2010, 70:5174-83.

32. Liu Y, Gao H, Marstrand TT, Ström A, Valen E, Sandelin A, Gustafsson JA, Dahlman-Wright $K$ : The genome landscape of ERalpha- and ERbetabinding DNA regions. Proc Natl Acad Sci USA 2008, 105:2604-2609.

33. Ambrosino C, Tarallo R, Bamundo A, Cuomo D, Franci G, Nassa G, Paris O, Ravo M, Giovane A, Zambrano N, Lepikhova T, Jänne OA, Baumann M, Nyman TA, Cicatiello L, Weisz A: Identification of a hormone-regulated 
dynamic nuclear actin network associated with estrogen receptor alpha in human breast cancer cell nuclei. Mol Cell Proteomics 2010, 9:1352-1367.

34. Cicatiello L, Addeo R, Sasso A, Altucci L, Petrizzi VB, Borgo R, Cancemi M, Caporali S, Caristi S, Scafoglio C, Teti D, Bresciani F, Perillo B, Weisz A: Estrogens and progesterone promote persistent CCND1 gene activation during $\mathrm{G} 1$ by inducing transcriptional derepression via c-Jun/c-Fos/ estrogen receptor (progesterone receptor) complex assembly to a distal regulatory element and recruitment of cyclin D1 to its own gene promoter. Mol Cell Biol 2004, 24:7260-7274.

35. Frasor J, Stossi F, Danes JM, Komm B, Lyttle CR, Katzenellenbogen BS: Selective estrogen receptor modulators: discrimination of agonistic versus antagonistic activities by gene expression profiling in breast cancer cells. Cancer Res 2004, 64:1522-1533.

36. Frasor J, Danes JM, Komm B, Chang KC, Lyttle CR, Katzenellenbogen BS: Profiling of estrogen up- and down-regulated gene expression in human breast cancer cells: insights into gene networks and pathways underlying estrogenic control of proliferation and cell phenotype. Endocrinology 2003, 144:4562-4574.

37. Buterin T, Koch C, Naegeli H: Convergent transcriptional profiles induced by endogenous estrogen and distinct xenoestrogens in breast cancer cells. Carcinogenesis 2006, 27:1567-1578.

38. Mardis ER: ChIP-seq: welcome to the new frontier. Nature methods 2007, 4:613-614.

39. Zhang Y, Liu T, Meyer CA, Eeckhoute J, Johnson DS, Bernstein BE, Nussbaum C, Myers RM, Brown M, Li W, Liu XS: Model-based analysis of ChIP-Seq (MACS). Genome Biol 2008, 9(9):R137.

40. Bailey $T L$, Elkan C: Fitting a mixture model by expectation maximization to discover motifs in biopolymers. Proc Int Conf Intell Syst Mol Biol 1994, 2:28-36.

41. Portales-Casamar E, Thongjuea S, Kwon AT, Arenillas D, Zhao X, Valen E, Yusuf D, Lenhard B, Wasserman WW, Sandelin A: JASPAR 2010: the greatly expanded open-access database of transcription factor binding profiles. Nucleic Acids Res 2010, 38:D105-10.

42. Mahony S, Auron PE, Benos PV: DNA familial binding profiles made easy: comparison of various motif alignment and clustering strategies. PLOS Comput Biol 2007, 3:e61.

43. Safe S, Kim K: Non-classical genomic estrogen receptor (ER)/specificity protein and ER/activating protein-1 signaling pathways. J Mol Endocrinol 2008, 41:263-275.

44. Vyhlidal C, Samudio I, Kladde MP, Safe S: Transcriptional activation of transforming growth factor alpha by estradiol: requirement for both a GC-rich site and an estrogen response element half-site. J Mol Endocrinol 2000, 24:329-338.

45. Webb P, Nguyen P, Valentine C, Lopez GN, Kwok GR, Mclnerney E, Katzenellenbogen BS, Enmark E, Gustafsson JA, Nilsson S, Kushner PJ: The estrogen receptor enhances AP-1 activity by two distinct mechanisms with different requirements for receptor transactivation functions. Mol Endocrinol 1999, 13:1672-1685.

46. Leung Y, Mak P, Hassan S, Ho S: Estrogen receptor (ER)-beta isoforms: a key to understanding ER-beta signaling. Proc Natl Acad Sci USA 2006, 103:13162-13167.

47. Weigelt K, Moehle C, Stempfl T, Weber B, Langmann T: An integrated workflow for analysis of ChIP-chip data. Biotechniques 2008, 45:131-132, 134, 136 passim.

48. Aulmann S, Bläker H, Penzel R, Rieker RJ, Otto HF, Sinn HP: CTCF gene mutations in invasive ductal breast cancer. Breast Cancer Res Treat 2003, 80:347-352.

49. Mattingly KA, Ivanova MM, Riggs KA, Wickramasinghe NS, Barch MJ, Klinge CM: Estradiol stimulates transcription of nuclear respiratory factor1 and increases mitochondrial biogenesis. Mol Endocrinol 2008, 22:609-622.

50. Granok H, Leibovitch B, Shaffer C: Ga-ga over GAGA factor. Curr Biol 1995, 5:238-241

51. Van Steensel B, Delrow J, Bussemaker HJ: Genomewide analysis of Drosophila GAGA factor target genes reveals context-dependent DNA binding. Proc Natl Acad Sci USA 2003, 100:2580-2585.

52. Bauer S, Grossmann S, Vingron M, Robinson PN: Ontologizer 2.0-a multifunctional tool for GO term enrichment analysis and data exploration. Bioinformatics 2008, 24:1650-1651.

53. Al-Nakhle $H$, Burns PA, Cummings $M$, Hanby AM, Hughes $T A$, Satheesha $S$, Shaaban AM, Smith L, Speirs V: Estrogen receptor \{beta\}1 expression is regulated by miR-92 in breast cancer. Cancer Res 2010, 70:4778-4784.
54. Bhat-Nakshatri P, Wang G, Collins NR, Thomson MJ, Geistlinger TR, Carroll JS, Brown M, Hammond S, Srour EF, Liu Y, Nakshatri H: Estradiolregulated microRNAs control estradiol response in breast cancer cells. Nucleic Acids Res 2009, 37:4850-4861.

55. Castellano L, Giamas G, Jacob J, Coombes RC, Lucchesi W, Thiruchelvam P, Barton G, Jiao LR, Wait R, Waxman J, Hannon GJ, Stebbing J: The estrogen receptor-alpha-induced microRNA signature regulates itself and its transcriptional response. Proc Natl Acad Sci USA 2009, 106:15732-15737.

56. Di Leva G, Gasparini P, Piovan C, Ngankeu A, Garofalo M, Taccioli C, Iorio MV, Li M, Volinia S, Alder H, Nakamura T, Nuovo G, Liu Y, Nephew KP, Croce CM: MicroRNA Cluster 221-222 and Estrogen Receptor \{alpha\} Interactions in Breast Cancer. J Natl Cancer Inst 2010, 102:706-721.

57. Maillot $G$, Lacroix-Triki M, Pierredon S, Gratadou L, Schmidt $S$, Bénès $V$, Roché H, Dalenc F, Auboeuf D, Millevoi S, Vagner S: Widespread estrogendependent repression of micrornas involved in breast tumor cell growth. Cancer Res 2009, 69:8332-8340.

58. Wickramasinghe NS, Manavalan TT, Dougherty SM, Riggs KA, Li Y, Klinge CM: Estradiol downregulates miR-21 expression and increases miR-21 target gene expression in MCF-7 breast cancer cells. Nucleic Acids Res 2009, 37:2584-2595.

59. Adams BD, Guttilla IK, White BA: Involvement of microRNAs in breast cancer. Semin Reprod Med 2008, 26:522-536.

60. Iorio MV, Ferracin M, Liu CG, Veronese A, Spizzo R, Sabbioni S, Magri E, Pedriali M, Fabbri M, Campiglio M, Ménard S, Palazzo JP, Rosenberg A, Musiani P, Volinia S, Nenci I, Calin GA, Querzoli P, Negrini M, Croce CM: MicroRNA gene expression deregulation in human breast cancer. Cancer Res 2005, 65:7065-7070.

61. Iorio MV, Casalini P, Tagliabue E, Ménard S, Croce CM: MicroRNA profiling as a tool to understand prognosis, therapy response and resistance in breast cancer. Eur J Cancer 2008, 44:2753-2759.

62. Yang SH, Liu R, Perez EJ, Wen Y, Stevens SM Jr, Valencia T, BrunZinkernagel AM, Prokai L, Will Y, Dykens J, Koulen P, Simpkins JW: Mitochondrial localization of estrogen receptor beta. Proc Natl Acad Sci USA 2004, 101:4130-4135.

63. Chen JQ, Eshete M, Alworth WL, Yager JD: Binding of MCF-7 cell mitochondrial proteins and recombinant human estrogen receptors alpha and beta to human mitochondrial DNA estrogen response elements. J Cell Biochem 2004, 93:358-373.

64. Chen J, Russo PA, Cooke C, Russo IH, Russo J: ERbeta shifts from mitochondria to nucleus during estrogen-induced neoplastic transformation of human breast epithelial cells and is involved in estrogen-induced synthesis of mitochondrial respiratory chain proteins. Biochim Biophys Acta 2007, 1773:1732-1746.

65. Felty Q, Singh KP, Roy D: Estrogen-induced G1/S transition of G0-arrested estrogen-dependent breast cancer cells is regulated by mitochondrial oxidant signaling. Oncogene 2005, 24:4883-4893.

66. Simpkins JW, Yang S, Sarkar SN, Pearce V: Estrogen actions on mitochondria-physiological and pathological implications. Mol Cell Endocrinol 2008, 290:51-59.

67. Blobel GA, Sieff CA, Orkin SH: Ligand-dependent repression of the erythroid transcription factor GATA-1 by the estrogen receptor. Mol Cell Biol 1995, 6:3147-3153.

68. Mao L, Wertzler K, Maloney SC, Wang Z, Magnuson NS, Reeves R: HMGA1 levels influence mitochondrial function and mitochondrial DNA repair efficiency. Mol Cell Biol 2009, 29:5426-5440.

69. Massaad-Massade L, Tacine R, Dulauroy S, Reeves R, Barouki R: The functional interaction between HMGA1 and the estrogen receptor requires either the $\mathrm{N}$ - or the $\mathrm{C}$-terminal domain of the receptor. FEBS Lett 2004, 559:89-95.

70. Pace P, Taylor J, Suntharalingam S, Coombes RC, Ali S: Human estrogen receptor beta binds DNA in a manner similar to and dimerizes with estrogen receptor alpha. J Biol Chem 1997, 272:25832-25838.

71. Pettersson K, Grandien K, Kuiper GG, Gustafsson JA: Mouse estrogen receptor beta forms estrogen response element-binding heterodimers with estrogen receptor alpha. Mol Endocrinol 1997, 11:1486-1496.

72. Li X, Huang J, Yi P, Bambara RA, Hilf R, Muyan M: Single-chain estrogen receptors (ERs) reveal that the ERalpha/beta heterodimer emulates functions of the ERalpha dimer in genomic estrogen signaling pathways. Mol Cell Biol 2004, 24:7681-7694. 
73. Andrews NC, Faller DV: A rapid micropreparation technique for extraction of DNA-binding proteins from limiting numbers of mammalian cells. Nucleic Acids Res 1991, 19:2499.

74. Frezza C, Cipolat S, Scorrano L: Organelle isolation: functional mitochondria from mouse liver, muscle and cultured fibroblasts. Nat Protoc 2007, 2:287-295.

75. Caporali S, Imai M, Altucci L, Cancemi M, Caristi S, Cicatiello L, Matarese F, Penta R, Sarkar DK, Bresciani F, Weisz A: Distinct signaling pathways mediate stimulation of cell cycle progression and prevention of apoptotic cell death by estrogen in rat pituitary tumor PR1 cells. Mol Biol Cell 2003, 14:5051-5059.

76. Bermont L, Lamielle-Musard F, Chezy E, Weisz A, Adessi GL: 17betaestradiol inhibits forskolin-induced vascular endothelial growth factor promoter in MCF-7 breast adenocarcinoma cells. J Steroid Biochem Mol Biol 2001, 78:343-349.

77. Licznar A, Caporali S, Lucas A, Weisz A, Vignon F, Lazennec G: Identification of genes involved in growth inhibition of breast cancer cells transduced with estrogen receptor. FEBS Lett 2003, 553:445-450.

78. Bonapace IM, Addeo R, Altucci L, Cicatiello L, Bifulco M, Laezza C, Salzano S, Sica V, Bresciani F, Weisz A: 17 beta-Estradiol overcomes a G1 block induced by HMG-CoA reductase inhibitors and fosters cell cycle progression without inducing ERK-1 and -2 MAP kinases activation. Oncogene 1996, 12:753-763.

79. Cicatiello L, Scafoglio C, Altucci L, Cancemi M, Natoli G, Facchiano A, lazzetti G, Calogero R, Biglia N, De Bortoli M, Sfiligoi C, Sismondi P, Bresciani F, Weisz A: A genomic view of estrogen actions in human breast cancer cells by expression profiling of the hormone-responsive transcriptome. J Mol Endocrinol 2004, 32:719-775.

80. Scafoglio C, Ambrosino C, Cicatiello L, Altucci L, Ardovino M, Bontempo P, Medici N, Molinari AM, Nebbioso A, Facchiano A, Calogero RA, Elkon R, Menini N, Ponzone R, Biglia N, Sismondi P, De Bortoli M, Weisz A: Comparative gene expression profiling reveals partially overlapping but distinct genomic actions of different antiestrogens in human breast cancer cells. J Cell Biochem 2006, 98:1163-1184.

81. Ravo M, Mutarelli M, Ferraro L, Grober OM, Paris O, Tarallo R, Vigilante $A$, Cimino D, De Bortoli M, Nola E, Cicatiello L, Weisz A: Quantitative expression profiling of highly degraded RNA from formalin-fixed, paraffin-embedded breast tumor biopsies by oligonucleotide microarrays. Lab Invest 2008, 88:430-440.

82. Cartharius K, Frech K, Grote K, Klocke B, Haltmeier M, Klingenhoff A, Frisch M, Bayerlein M, Werner T: MatInspector and beyond: promoter analysis based on transcription factor binding sites. Bioinformatics 2005, 21:2933-2942.

83. Ho Sui SJ, Fulton DL, Arenillas DJ, Kwon AT, Wasserman WW: oPOSSUM: identification of over-represented transcription factor binding sites in co-expressed genes. Nucleic Acids Res 2005, 33:3154-64.

84. Saeed Al, Sharov V, White J, Li J, Liang W, Bhagabati N, Braisted J, Klapa M, Currier T, Thiagarajan M, Sturn A, Snuffin M, Rezantsev A, Popov D, Ryltsov A, Kostukovich E, Borisovsky I, Liu Z, Vinsavich A, Trush V, Quackenbush J: TM4: a free, open-source system for microarray data management and analysis. Biotechniques 2003, 34:374-378.

85. Kuhn RM, Karolchik D, Zweig AS, Wang T, Smith KE, Rosenbloom KR, Rhead B, Raney BJ, Pohl A, Pheasant M, Meyer L, Hsu F, Hinrichs AS, Harte RA, Giardine B, Fujita P, Diekhans M, Dreszer T, Clawson H, Barber GP, Haussler D, Kent WJ: The UCSC Genome Browser Database: update 2009. Nucleic Acids Res 2009, 37(Database issue):D755-761.

doi:10.1186/1471-2164-12-36

Cite this article as: Grober et al:: Global analysis of estrogen receptor beta binding to breast cancer cell genome reveals an extensive interplay with estrogen receptor alpha for target gene regulation. BMC Genomics 2011 12:36.

\section{Submit your next manuscript to BioMed Central and take full advantage of:}

- Convenient online submission

- Thorough peer review

- No space constraints or color figure charges

- Immediate publication on acceptance

- Inclusion in PubMed, CAS, Scopus and Google Scholar

- Research which is freely available for redistribution

Submit your manuscript at www.biomedcentral.com/submit
Biomed Central 